Antarctic Science 34(1), 58-78 (2022) C The Author(s), 2022. Published by Cambridge

University Press on behalf of Antarctic Science Ltd. This is an Open Access article,

distributed under the terms of the Creative Commons Attribution licence (https://

creativecommons.org/licenses/by/4.0/), which permits unrestricted re-use, distribution,

and reproduction in any medium, provided the original work is properly cited.

doi:10.1017/S0954102021000560

\title{
Sediment and water geochemistry record of water-rock interactions in King George Island, Antarctic Peninsula
}

\author{
YAGMUR GUNES 1 1,2 and NURGUL BALCI 1 1,2 \\ ${ }^{1}$ Department of Geological Engineering, Geomicrobiology and Biogeochemistry Laboratory, Istanbul Technical University, Istanbul, \\ Turkey \\ ${ }^{2}$ ITU Faculty of Mines, Department of Geological Engineering, Ayazaga Campus, 34469 Maslak, Istanbul, Turkey \\ ncelik@itu.edu.tr
}

\begin{abstract}
We used a multidisciplinary approach integrating major, trace and rare earth element geochemistry, mineralogy of rocks and sediments along with the ionic composition of water reservoirs of Admiralty Bay, King George Island, to evaluate the record of water-rock interactions under Maritime Antarctic conditions. Our results showed that the ionic compositions of the streams and meltwaters predominantly reflect the atmospheric inputs, while lake waters have higher $\mathrm{Na} / \mathrm{Cl}, \mathrm{Ca} / \mathrm{Mg}$ and $\mathrm{HCO}_{3} / \mathrm{Cl}$ ratios related to chemical weathering in lake sediments, but this did not allow for distinguishing purely silicate sources. Consistent with the trace and rare earth element data, various alteration indices and Index of Compositional Variability values denote the low degree of chemical weathering in the lake sediments. The records from the previously unexplored Mud Lake and Upper Lake suggest that the lakes of Admiralty Bay are better places to trace the impacts of a succession of environmental changes that have occurred in the watershed, while the stream channel sediments, when accompanied by water chemistry data, may provide a more representative composition of the source rocks than the lake sediments. These findings may help revealing the intensity of contemporary weathering in a colder climate with relatively few mineralogical changes accompanied by a lesser degree of elemental loss.
\end{abstract}

Received 18 June 2021, accepted 26 August 2021

Key words: aerosol, chemical index of alteration, REE, trace elements, weathering

\section{Introduction}

Mafic rock weathering (e.g. basalt), involving chemical and physical processes, is a major process that governs the release and mobility of elements, thus profoundly impacting the geochemical compositions of rivers, seawater, soils and sediments under the various surface conditions of the Earth, which feed back into the long-term evolution of Earth's climate (Sharp et al. 1995, Elango \& Kannan 2007). By influencing the geochemical characteristics of different components of Earth, water-rock interactions may leave geochemical and mineralogical signals in newly formed sediments of different water reservoirs that, along with their water chemistry, can be used to interpret the source of the primary materials.

Revealing the geochemical records of mafic rock weathering in particularly cold and dry regions such as Continental Antarctica and the sub-Antarctic has been the focus of intensive research (Marra et al. 2015, Kim et al. 2020), as they have implications for the effects of changing climatic conditions on the global carbon cycle on Earth and for sedimentary processes on Mars dominated by a basaltic crust (Rutledge et al. 2018, Thorpe et al. 2019).

Chemical weathering and physical weathering generating sediments are often coupled during weathering processes. Compared to Continental Antarctica, enhanced rock weathering is expected in Maritime Antarctic regions due to the presence of a larger deglaciated area where fresh rock surfaces are created and exposed to increasing summer temperatures (Vasyukova et al. 2019). Water and sediment geochemistry as well as secondary products (e.g. clay minerals) are geochemical archives that can be used to trace the source rocks that contribute to sediment and water geochemistry. For example, the formation of clay minerals is often correlated with the intensity of chemical weathering, and various types of clay minerals (e.g. vermiculite, smectite clays) are reported as evidence for chemical weathering in the Maritime Antarctic (Vasyukova et al. 2019). However, the factors controlling the geochemical and mineralogical compositions of the sediment and water chemistry characteristics of different reservoirs are 


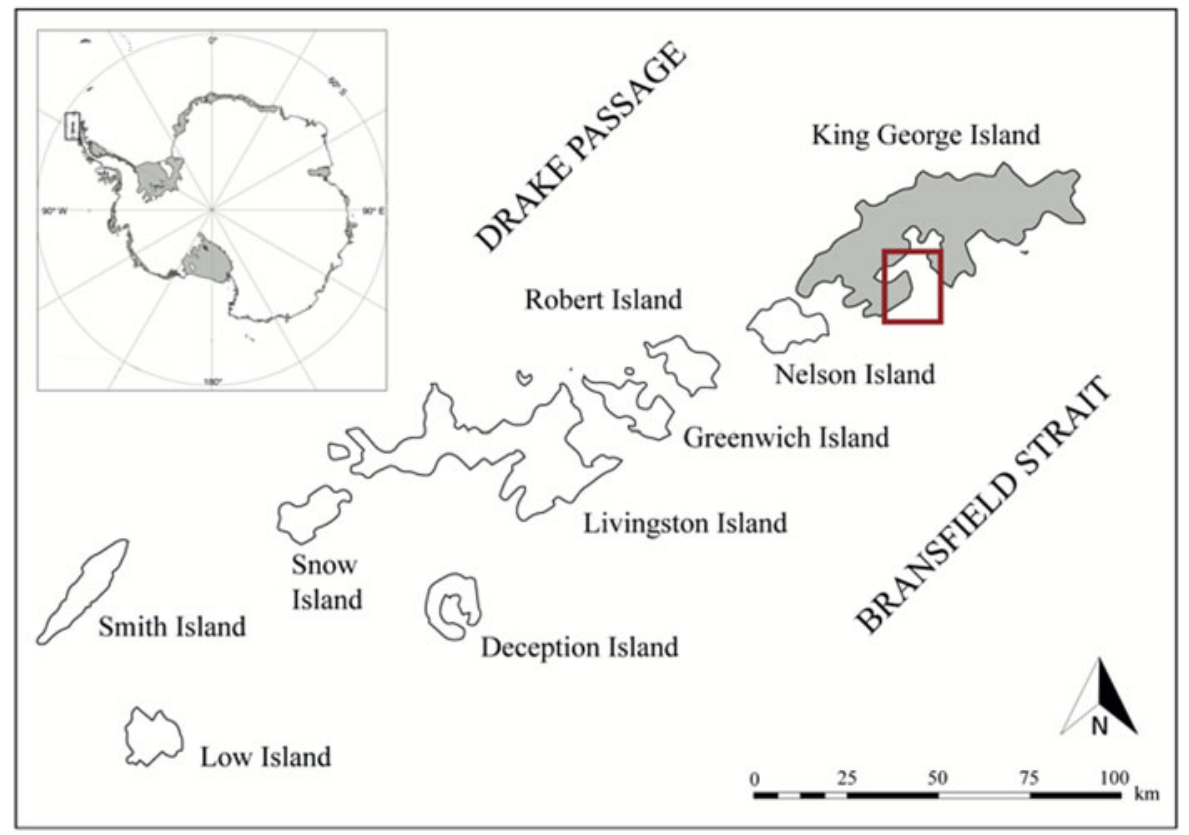

Fig. 1. Location map of Admiralty Bay, King George Island, South Shetland Island Group, Antarctica.

complex. Dissolution mechanisms and elemental flux of mafic/ultramafic Maritime Antarctic rocks have been investigated experimentally by Gunes \& Balci (2021), including the effects of microorganisms. There are unfortunately few studies dealing with the water and particularly sediment geochemistry records of different reservoirs of the Maritime Antarctic (i.e. King George Island; KGI). Furthermore, the sources of the chemical constituents within the various water reservoirs (e.g. lakes, streams) are not clearly known. The chemical composition of fresh water is limited to a few studies carried out primarily on Livingston Island (Toro et al. 2007), James Ross Island (Hawes \& Brazier 1991) and the western shore of Admiralty Bay (Nedzarek et al. 2015, Zwoliński et al. 2016).

The western shore of Admiralty Bay, located in KGI in the Maritime Antarctic, is characterized by mild temperatures and considerable precipitation along with a large ice-free area underlain predominantly by mafic rocks. This Maritime Antarctic site offers an excellent opportunity to reveal the influence of contemporary rock weathering on the water and sediment geochemistry of various freshwater reservoirs created by glacial meltwater in the form of ephemeral and perennial streams and lakes. Although the geology (Birkenmajer 2003, Mozer 2012), hydrology/hydrogeology (Szopińska et al. 2018, Potapowicz et al. 2020) and sediment geochemistry (Santos et al. 2007, Mozer 2012) of the western shore of Admiralty Bay have been studied over the years, the rock weathering processes and associated geochemical fingerprints linked to widespread deglaciation processes have not been comprehensively studied. By conducting this research, we attempt to answer the following main questions: 1) What are the main sources influencing the water and sediment geochemistry under the influence of the Maritime Antarctic climate? 2) To what extent are the weathering processes faithfully reflected in the sediment and water geochemistry as well as in the secondary mineral products? To improve our current understanding of rock weathering processes and their geochemical records under Maritime Antarctic conditions, we use an integrated approach composed of studying the partitioning of major and trace elements among the different reservoirs (rocks, sediments, water), along with their mineralogical and geochemical compositions. For this purpose, various rocks, sediments and surface waters from perennial and ephemeral streams, lakes and meltwaters were collected within the western shore of Admiralty Bay, KGI, South Shetland Islands (SSIs), Antarctic Peninsula.

\section{Description of study area}

The main study area, the western coast of Admiralty Bay, is located in KGI, the largest of the SSIs, which are sited on the northernmost part of the Antarctic Peninsula. The island group is separated from the Antarctic Peninsula by the Bransfield Strait extension (Fig. 1). The study area is a part of the Warszawa Block (Birkenmajer 2003) with an $\sim 1310 \mathrm{~km}^{2}$ surface area. The majority of the surface area $(\sim 90 \%)$ is permanently glaciated, and permafrost processes are generally restricted to the 


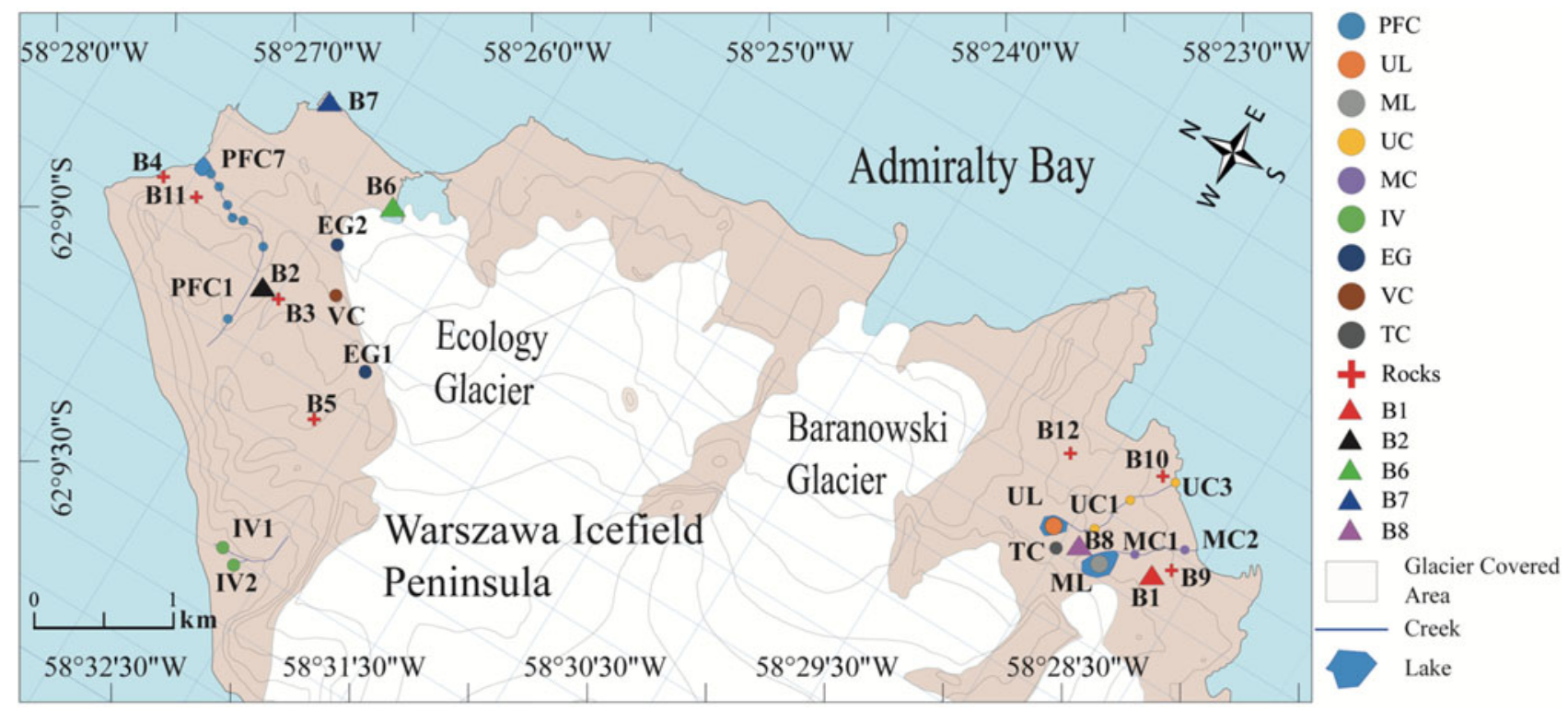

Fig. 2. Field sampling points of the studied areas. Each circle indicates water and the associated sediment, and the triangles and crosses indicate mineralogically and elementally characterized rocks, respectively. EG = Ecology Glacier Creek; IV = Italian Valley Creek; MC = Mud Creek; ML = Mud Lake; PFC = Petrified Forest Creek; TC = Tower Creek; UC = Upper Creek; UL = Upper Lake; $\mathrm{VC}=$ Vanishing Creek.

ice-free area. Recent studies conducted on the SSIs show that permafrost ranging from 20 to $100 \mathrm{~cm}$ in thickness is most common in the ice-free areas of the sub-Antarctic region (López-Martínez et al. 2012).

From south to west, the elevation of the terrain changes from 60 to $170 \mathrm{~m}$ above sea level. The area is under the influence of the sub-polar and Maritime Antarctic climate, characterized by short-term weather and current variability (e.g. year to year) resulting from the interactions between the ocean, atmosphere and sea ice (Oerlemans \& Fortuin 1992). The annual average temperature range is -1.8 to $+4^{\circ} \mathrm{C}$. The annual humidity is $82 \%$ and the pressure is $991 \mathrm{hPa}$. In general, the area is characterized by rainfall and snowfall, with the mean annual precipitation rate being $550 \mathrm{~mm}$ near Arctowski Station, Admiralty Bay (Beyer 2002). Ice-free areas are locally vegetated with mosses and lichens.

The main study area, the western shore of Admiralty Bay, is located on the Warszawa Block, KGI, where the ages of the stratigraphic units range from Late Cretaceous to Early Miocene. The studied area is composed of volcanic, volcanoclastic and, to a lesser extent, sedimentary rocks. Volcanic units range from basalt to dacite in composition, while sedimentary units are mostly composed of conglomerate and shale. The hypabyssal intrusions are in the form of basalt-andesite plugs and dykes. Overall, $\mathrm{K}_{2} \mathrm{O}$ abundance of the area is in the range of the calc-alkaline series (Birkenmajer et al. 1991).

The majority of the sampling area is in Antarctic Specially Protected Area (ASPA) No. 128 and comprises 46 streams ranging from small (meltwater) to continuously running perennial streams, along with 36 lakes and ponds. Most of the surface water sources are ephemeral, being fed by glacial melt and/or snowmelt. The presence of a permafrost layer inhibiting infiltration limits detailed hydrological study due to the inconsistency and difficulty of determining the amounts and exact flows of the streams (i.e. short freeze-thaw cycle) (Zwoliński et al. 2012).

The current research was conducted on seven streams, two previously uncharacterized lakes and one glacier located on the largest ice-free area of KGI (Fig. 2). The Petrified Forest Creek (PFC), at $1.62 \mathrm{~km}$ in length, represents the longest stream fed by snowmelt, rainfall and permafrost thaw, draining the ice-free area to the south-west and south of the Henryk Arctowski Polish Antarctic Station. During summer, its flow rate changes from 10 to $50 \mathrm{~m}^{3} \mathrm{~s}^{-1}$ (Szopińska et al. 2018), and PFC is classified as a non-glaciated catchment without tundra. Italian Valley Creek (IV), located at the shore of Ezcurra Inlet and probably fed by permafrost thaw, shows weak but continuous water flow over various types of moraines until it reaches the bay. Similarly, Vanishing Creek (VC) flows over fine-grained moraines with a low discharge. These two creeks are fed by Ecology Glacier. Ecology Glacier Creek (EG) drains the immediate forefield of Ecology Glacier and flows on poorly sorted moraine deposits with contributions of snow patch melt. The other three small streams studied for the first time are associated with Upper Lake (UL), Mud Lake (ML) and Tower Glacier and are named as 'Upper Creek' (UC), 'Mud Creek' (MC) and 'Tower Creek' (TC). UL 
and ML are both located on Paradise Cove in the Demay region. UL is dominantly fed by Tower Glacier (Fig. 2), and the stability of the lake is therefore highly dependent on daily and seasonal atmospheric conditions. Compared to UL, ML is located in a more preserved area covered by high topography. The catchment areas in close proximity to the lakes are generally barren, deglaciated landscapes with the occasional presence of mosses and lichens. Currently, there is no available information on either the hydrological or the geochemical properties of the lakes, and this study provides the first detailed research on these lakes.

\section{Material and methods}

\section{Field sampling and measurements}

The field excursion was conducted at the end of the summer of 2018 (17 March-12 April) to collect rocks, sediments and surface water samples from the western shore of Admiralty Bay. A list of rocks, sediments and surface water samples is presented in Table S1. Representative bedrocks $(n=12)$ were collected within Admiralty Bay (Fig. 2). Surface water and sediment samples were collected from lakes (UL at six different points and ML at five different points; Fig. S1) and streams (PFC at seven different points, UC at three different points, IV, MC and EG at two different points and $\mathrm{TC}$ and $\mathrm{VC}$ at one different point; Fig. S2 \& Table S1). The sediment and water samples were labelled with the stream and lake names. The lowest-numbered sample indicates that the sample was collected nearest to or at the mount of the stream. A careful sampling strategy was applied to collect samples in particular waters, at the mouth and ends of the creeks and near the middle of the flow channel, if possible. The sampling was also undertaken in such a way as to minimize contamination (e.g. human-induced), and polyethylene gloves were used during the sampling. Water samples $(n=29)$ were manually collected into 11 high-density polyethylene (HDPE) bottles, and each bottle was rinsed with the respective surface water three times before filling. Subsequently, the first $200 \mathrm{ml}$ of water was immediately filtered through sterile, single-use Millipore filters $(0.2 \mu \mathrm{m})$ and $100 \mathrm{ml}$ was acidified with ultrapure $\mathrm{HNO}_{3}$ acid ( $\mathrm{pH}<2$; Merck) for cation and trace metal analysis, stored in HDPE bottles previously washed with ultrapure HCI (0.1 M; Merck) and rinsed with ultrapure water, and the rest of the filtered water was preserved for anion analysis without acidification. All bottles were filled completely to prevent possible evaporation into the headspace and further covered by parafilm and stored at $+4^{\circ} \mathrm{C}$ until being analysed. After sampling, analysis of the physicochemical properties of the unfiltered water samples $(\mathrm{pH}$, electrical conductivity (EC) and temperature) as well as total dissolved solid (TDS) measurements were performed in situ by using a pre-calibrated WTW multiprobe (WTW 303). Before the measurements, the $\mathrm{pH}$ electrode was calibrated against a NIST buffer solutions ( $\mathrm{pH}=4$ and 6.8 at $25^{\circ} \mathrm{C}$ ) with an accuracy of $\pm 0.03 \mathrm{pH}$ units.

Surface sediments were manually collected from each water (lake and stream) sampling point with a pre-sterilized metal spoon. Upon collection, each sediment sample was stored in an airtight sterile plastic sampling bag, and all samples $(n=27)$ were stored at $+4^{\circ} \mathrm{C}$ until being analysed.

\section{Chemical analysis of streams, lakes and meltwaters}

Major anions $\left(\mathrm{SO}_{4}^{2-}, \mathrm{NO}_{2}^{-}, \mathrm{NO}_{3}^{-}, \mathrm{F}^{-}, \mathrm{CaCO}_{3}, \mathrm{HCO}_{3}^{-}, \mathrm{CO}_{3}^{2-}\right.$ and $\left.\mathrm{Br}^{-} ; n=5\right)$, cations $\left(\mathrm{Mg}^{2+}, \mathrm{Ca}^{2+}, \mathrm{K}^{+}\right.$and $\left.\mathrm{Na}^{+}\right)$and trace element concentrations $(n=29)$ were measured using ion chromatography (Dionex ICS 2000) and inductively coupled plasma-mass spectrometry with uncertainties of $5 \%$ and $2 \%$, respectively, at ACME Bureau Veritas Mineral Laboratories (Canada). Alkalinity was measured by using a MColortest ${ }^{\mathrm{TM}}$ 111109 test (acid capacity to $\mathrm{pH} 8.2$ and 4.3 ; titrimetric method with an MQuant ${ }^{\circledR}$ titration pipette).

\section{Chemical and mineralogical analysis of rocks and sediments}

Mineralogical analysis of both altered and unaltered rock samples was performed on polished thin sections $(n=12)$ using a Leica DM 750P polarized microscope and X-ray diffractometer (XRD) at Istanbul Technical University (ITU) Laboratory. Unaltered representative rock samples $(n=5)$ and sediment samples $(n=27)$ previously dried at $50^{\circ} \mathrm{C}$ in a desiccating oven overnight were carefully crushed, pulverized and homogenized. The sediment samples were further sieved through a $2 \mathrm{~mm}$ sieve and powdered rock and sediment samples were used for major and trace element analyses. Elemental analyses were performed at ACME Bureau Veritas Mineral Laboratories (Procedure Code: MA250).

For XRD analysis, rock and sediment samples that had been previously crushed and ground to powder were thoroughly rinsed with deionized water and acetone. The samples were then collected on a silicon sample holder and measurements were performed with a D8 Advance Bruker diffractometer using $\mathrm{Cu}-K \alpha$ radiation. Data were collected between $2^{\circ}$ and $72^{\circ}$ with a total counting time of $15 \mathrm{~min}$. The X'Pert HighScore Plus software was used for background subtraction, peak identification and matching with XRD patterns of reference compounds (US Institute of Standards and Technology).

The grain size distributions of the representative sediment samples obtained from lakes (ML $(n=1)$ and 
Table I. Physicochemical, major anion and cation compositions of waters.

\begin{tabular}{|c|c|c|c|c|c|c|c|c|c|c|c|c|c|c|c|c|c|c|c|}
\hline Sample & Remarks & $\mathrm{pH}$ & $\begin{array}{c}\mathrm{T} \\
{ }^{\circ} \mathrm{C}\end{array}$ & $\begin{array}{c}\mathrm{EC} \\
\mu \mathrm{S} / \mathrm{cm}\end{array}$ & $\begin{array}{l}\text { TDS } \\
\text { ppm }\end{array}$ & $\underset{\mathrm{mmol}}{\mathrm{Ca}}$ & $\begin{array}{c}\mathrm{K} \\
\mathrm{mmol}\end{array}$ & $\begin{array}{c}\mathrm{Mg} \\
\mathrm{mmol}\end{array}$ & $\begin{array}{c}\mathrm{Na} \\
\mathrm{mmol}\end{array}$ & $\begin{array}{c}\mathrm{Si} \\
\mathrm{mmol}\end{array}$ & $\begin{array}{c}\mathrm{Fe} \\
\mathrm{mmol}\end{array}$ & $\begin{array}{c}\mathrm{Al} \\
\mathrm{mmol}\end{array}$ & $\begin{array}{c}\mathrm{Cl} \\
\mathrm{mmol}\end{array}$ & $\begin{array}{c}\mathrm{HCO}_{3} \\
\mathrm{mmol}\end{array}$ & $\begin{array}{c}\mathrm{SO}_{4} \\
\mathrm{mmol}\end{array}$ & $\begin{array}{l}\mathrm{NO}_{3} \\
\mathrm{mmol}\end{array}$ & $\begin{array}{c}\mathrm{NO}_{2} \\
\mathrm{mmol}\end{array}$ & $\begin{array}{c}\mathrm{F} \\
\mathrm{mmol}\end{array}$ & $\begin{array}{c}\mathrm{Br} \\
\mathrm{mmol}\end{array}$ \\
\hline PFC1 & Stream & 8.3 & & 240 & 120 & 0.297 & 0.009 & 0.173 & 1.506 & 0.098 & 0.011 & 0.028 & 1.156 & 0.450 & 0.031 & n.a. & n.a. & n.a. & n.a. \\
\hline $\mathrm{PFC} 2$ & & 8.0 & & 220 & 110 & 0.257 & 0.015 & 0.168 & 1.391 & 0.092 & 0.015 & 0.015 & 1.100 & 0.550 & 0.042 & 0.001 & bdl & 0.0010 & 0.0019 \\
\hline PFC3 & & 8.2 & & 160 & 80 & 0.244 & 0.010 & 0.117 & 1.283 & 0.080 & 0.011 & 0.013 & 0.903 & 0.400 & 0.042 & n.a. & n.a. & n.a. & n.a. \\
\hline PFC4 & & 8.0 & & 170 & 80 & 0.208 & 0.009 & 0.082 & 1.297 & 0.084 & 0.000 & 0.016 & 0.790 & 0.550 & 0.052 & n.a. & n.a. & n.a. & n.a. \\
\hline PFC5 & & 8.3 & & 170 & 80 & 0.235 & 0.010 & 0.114 & 1.290 & 0.080 & 0.012 & 0.023 & 0.846 & 0.400 & 0.000 & n.a. & n.a. & n.a. & n.a. \\
\hline PFC6 & & 8.0 & & 180 & 90 & 0.229 & 0.009 & 0.116 & 1.332 & 0.082 & 0.119 & 0.04 & 0.846 & 0.450 & 0.042 & n.a. & n.a. & n.a. & n.a. \\
\hline PFC7 & & 8.0 & & 160 & 80 & 0.240 & 0.011 & 0.135 & 1.365 & 0.083 & 0.017 & 0.019 & 1.015 & 0.350 & 0.042 & 0.0016 & bdl & 0.0014 & 0.0018 \\
\hline UL1 & Lake & 8.1 & & 100 & 50 & 0.225 & 0.012 & 0.051 & 1.074 & 0.042 & 0.115 & 0.188 & 0.621 & 0.550 & 0.021 & n.a. & n.a. & n.a. & n.a. \\
\hline UL2 & & 8.3 & & 190 & 90 & 0.256 & 0.011 & 0.058 & 1.482 & 0.046 & 0.043 & 0.072 & 0.762 & 0.280 & 0.010 & n.a. & n.a. & n.a. & n.a. \\
\hline UL3 & & 8.2 & & 190 & 90 & 0.269 & 0.007 & 0.053 & 1.480 & 0.044 & 0.035 & 0.044 & 0.733 & 0.380 & 0.000 & 0.0009 & 0.0005 & 0.0013 & 0.0004 \\
\hline UL4 & & 8. & & 190 & 90 & 0.251 & 0.007 & 0.051 & 1.437 & 0.043 & 0.018 & 0.039 & 0.733 & 0.300 & 0.000 & n.a. & n.a. & n.a. & n.a. \\
\hline UL5 & & 8.2 & & 190 & 90 & 0.259 & 0.007 & 0.052 & 1.432 & 0.045 & 0.01 & 0.026 & 0.733 & 0.600 & 0.031 & n.a. & n.a. & n.a. & n.a. \\
\hline UL6 & & 7.9 & & 170 & 80 & 0.264 & 0.010 & 0.063 & 1.510 & 0.052 & 0.082 & 0.133 & 0.818 & 0.800 & 0.281 & n.a. & n.a. & n.a. & n.a. \\
\hline ML1 & Lake & 8.0 & & 110 & 50 & 0.188 & 0.005 & 0.028 & 1.296 & 0.054 & 0.028 & 0.046 & 0.338 & 0.750 & 0.021 & n.a. & n.a. & n.a. & n.a. \\
\hline ML2 & & 8.3 & & 160 & 80 & 0.251 & 0.006 & 0.035 & 1.440 & 0.056 & 0.018 & 0.041 & 0.536 & 0.700 & 0.031 & 0.0005 & 0.0007 & 0.0019 & 0.0009 \\
\hline ML3 & & 8.3 & & 170 & 80 & 0.236 & 0.006 & 0.032 & 1.583 & 0.060 & 0.020 & 0.046 & 0.536 & 0.520 & 0.000 & n.a. & n.a. & n.a. & n.a. \\
\hline ML4 & & 8.2 & & 160 & 80 & 0.243 & 0.005 & 0.030 & 1.503 & 0.054 & 0.025 & 0.027 & 0.508 & 0.880 & 0.052 & n.a. & n.a. & n.a. & n.a. \\
\hline ML5 & & 8.0 & & 160 & 80 & 0.238 & 0.005 & 0.033 & 1.399 & 0.051 & 0.000 & 0.017 & 0.508 & 1.000 & 0.031 & n.a. & n.a. & n.a. & n.a. \\
\hline $\mathrm{UC1}$ & Stream as outflow & 8.1 & & 260 & 130 & 0.426 & 0.007 & 0.087 & 1.813 & 0.062 & 0.073 & 0.035 & 0.762 & 0.280 & 0.010 & n.a. & n.a. & n.a. & n.a. \\
\hline $\mathrm{UC} 2$ & & 9.0 & & 230 & 120 & 0.305 & 0.006 & 0.070 & 1.798 & 0.061 & 0.010 & 0.027 & 0.733 & 0.380 & 0.000 & n.a. & n.a. & n.a. & n.a. \\
\hline UC3 & & 8.2 & & 220 & 110 & 0.307 & 0.006 & 0.063 & 1.782 & 0.059 & 0.029 & 0.046 & 0.733 & 0.300 & 0.000 & n.a. & n.a. & n.a. & n.a. \\
\hline $\mathrm{MC1}$ & Stream as outflow & 8.4 & & n.a. & 96 & 0.190 & 0.005 & 0.022 & 1.246 & 0.052 & 0.015 & 0.034 & 0.818 & 0.800 & 0.281 & bdl & 0.0004 & 0.0018 & 0.0005 \\
\hline $\mathrm{MC} 2$ & & 8.6 & & n.a. & 69 & 0.271 & 0.008 & 0.049 & 1.747 & 0.062 & 0.000 & 0.042 & 0.903 & 0.450 & 0.031 & n.a. & n.a. & n.a. & n.a. \\
\hline IV1 & Stream & n.a. & & n.a. & 131 & 0.090 & 0.011 & 0.080 & 0.868 & 0.062 & 0.000 & 0.013 & 1.100 & 0.450 & 0.042 & n.a. & n.a. & n.a. & n.a. \\
\hline IV2 & & n.a. & & n.a. & 72 & 0.134 & 0.010 & 0.049 & 0.980 & 0.030 & 0.012 & 0.012 & 1.015 & 0.350 & 0.042 & n.a. & n.a. & n.a. & n.a. \\
\hline TC & Stream & 8.2 & & 250 & 120 & 0.430 & 0.008 & 0.076 & 1.923 & 0.063 & 0.057 & 0.13 & 1.156 & 0.400 & 0.000 & n.a. & n.a. & n.a. & n.a. \\
\hline EG1 & Frontline meltwater & n.a. & & n.a. & 39 & 0.090 & 0.011 & 0.080 & 0.868 & 0.062 & 0.000 & 0.029 & 1.100 & 0.450 & 0.042 & n.a. & n.a. & n.a. & n.a. \\
\hline EG2 & & n.a. & & n.a. & 25 & 0.134 & 0.010 & 0.049 & 0.980 & 0.030 & 0.031 & 0.046 & 1.015 & 0.350 & 0.042 & n.a. & n.a. & n.a. & n.a. \\
\hline $\mathrm{VC}$ & Frontline meltwater & 8.2 & & n.a. & 41 & 0.254 & 0.015 & 0.142 & 1.670 & 0.115 & 0.000 & 0.012 & 0.846 & 0.550 & 0.052 & n.a. & n.a. & n.a. & n.a. \\
\hline
\end{tabular}

$\mathrm{bdl}=$ below detection limits; EC = electrical conductivity; EG = Ecology Glacier Creek; IV = Italian Valley Creek; MC = Mud Creek; ML = Mud Lake; $\mathrm{n} . \mathrm{a} .=$ not analysed; PFC = Petrified Forest

Creek; $\mathrm{T}=$ temperature; $\mathrm{TC}=$ Tower Creek; TDS $=$ total dissolved solids; $\mathrm{UC}=$ Upper Creek; UL = Upper Lake; VC $=$ Vanishing Creek. 


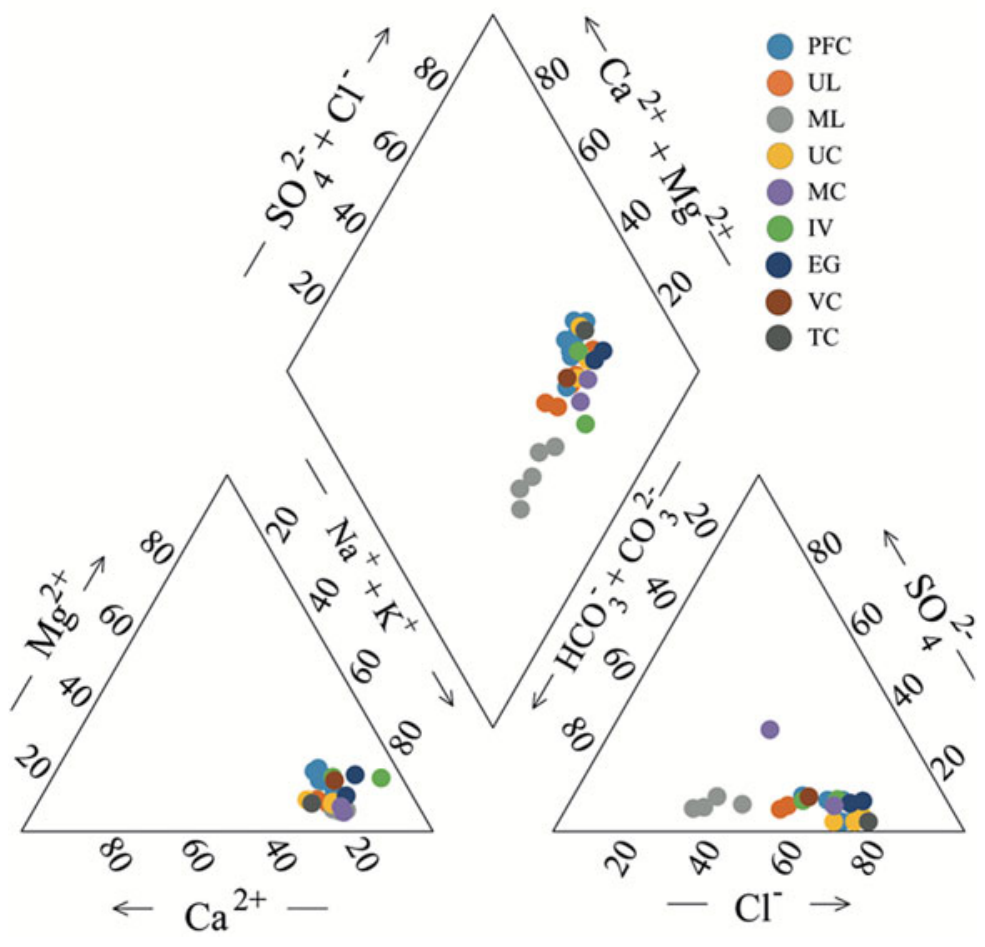

Fig. 3. Piper diagram showing the relative abundances of the major ion concentrations of the water samples. $\mathrm{EG}=$ Ecology Glacier Creek; IV = Italian Valley Creek; MC = Mud Creek; ML = Mud Lake; $\mathrm{PFC}=$ Petrified Forest Creek; $\mathrm{TC}=$ Tower Creek; $\mathrm{UC}=$ Upper Creek; UL = Upper Lake; $\mathrm{VC}=$ Vanishing Creek.
$\mathrm{UL}(n=1))$ and streams (PFC $(n=7), \mathrm{MC}(n=1)$ and UC $(n=1))$ were analysed. First, bulk sediment samples were sieved by using ASTM mesh sizes of 230, 200, 140, 60, 35 and 10. After removing the particles $>2 \mathrm{~mm}$, Mastersizer analysis was conducted on the remaining sediments by using sodium hexametaphosphate as a dispersant (Mastersizer 3000 User Manual (Mano474 Issue 2.1, August 2013)). Each analysis was run three times with ultrasound on and the particle size percentages were obtained via Mastersizer 3000 software.

The total organic carbon (TOC) content of the sediments was analysed by using the Walkley-Black (WB) chromic acid wet oxidation method (Gaudette et al. 1974, Sar1 et al. 2013). In brief, concentrated $\mathrm{H}_{2} \mathrm{SO}_{4}$ is added to a mixture of sediment and $1 \mathrm{~N}$ aqueous $\mathrm{K}_{2} \mathrm{Cr}_{2} \mathrm{O}_{7}$. The heat resulting from the addition of $\mathrm{H}_{2} \mathrm{SO}_{4}$ raises the temperature sufficiently to induce substantial oxidation. Residual dichromate is titrated by ferrous sulphate. The difference in added $\mathrm{FeSO}_{4}$ compared with a blank titration gives the amount of easily oxidisable organic carbon. The percentage of WB carbon (WBC) is given by the following formula:

$$
\mathrm{WBC}=M \times\left(V_{1}-V_{2}\right) / W \times 0.30 \times \mathrm{CF}
$$

where $M$ is the molarity of the $\mathrm{FeSO}_{4}$ solution (from blank titration), $V_{1}$ is the volume $(\mathrm{ml})$ of $\mathrm{FeSO}_{4}$ required in blank titration, $V_{2}$ is the volume $(\mathrm{ml})$ of $\mathrm{FeSO}_{4}$ required in actual titration and $W$ is the weight $(\mathrm{g})$ of the dried sediment sample. The correction factor $(\mathrm{CF})$ acts as a compensation for the incomplete oxidation and is the inverse of the recovery, set by Walkley \& Black (1934) to 1.32 (recovery of $76 \%$ ).

\section{Results}

Basic characteristics and major ion chemistry of fresh water

In general, all water samples, regardless of the sampling location and type, have slightly alkaline characteristics, with $\mathrm{pH}$ values ranging from 7.9 to 9.0 and EC values ranging from 100 to $260 \mu \mathrm{S} / \mathrm{cm}$ (Table I). The TDS values varied from 50 to $260 \mathrm{ppm}$ with an average of $85 \mathrm{ppm}$. Compared to the lakes, stream waters have high TDS values. In general, major cations in all the water samples exhibit similar values. On a molar basis, $\mathrm{Na}^{+}$ accounts for $>65 \%$ of the total cations, while $\mathrm{K}^{+}$ represents a minor component of the water samples $(<1.5 \%)$. Compared to $\mathrm{Na}^{+}, \mathrm{Ca}^{2+}$ and $\mathrm{Mg}^{2+}$ commonly account for $>20 \%$ of the total cations; averaging $\sim 29 \%$ $\left(22 \% \mathrm{Ca}^{2+}\right)$ in the PFC, $27 \%\left(24 \% \mathrm{Ca}^{2+}\right)$ in the UC, $23 \%\left(21 \% \mathrm{Ca}^{2+}\right)$ in the MC, $20 \%\left(13 \% \mathrm{Ca}^{2+}\right)$ in the IV, $28 \%\left(25 \% \mathrm{Ca}^{2+}\right)$ in the TC, $24 \%\left(18 \% \mathrm{Ca}^{2+}\right)$ in the VC and $21 \%\left(16 \% \mathrm{Ca}^{2+}\right)$ in the EG meltwater. Similarly, $\mathrm{Ca}^{2+}$ and $\mathrm{Mg}^{2+}$ in the lake waters account for $26 \%(23 \%$ $\left.\mathrm{Ca}^{2+}\right)$ and $23 \%\left(21 \% \mathrm{Ca}^{2+}\right)$ of the total cations in the $\mathrm{UL}$ and $\mathrm{ML}$, respectively. $\mathrm{HCO}_{3}^{-}$is the most abundant anion in the $\mathrm{ML}$, accounting for an average of $68 \%$ of total anions, while it is the second most abundant anion (47\% of total anions) in the UL. Averages of $63 \%$ and 
Table II. Major oxide, total organic carbon (TOC), loss on ignition (LOI), Index of Compositional Variability (ICV), Chemical Index of Alteration (CIA), Plagioclase Index of Alteration (PIA) and Mafic Index of Alteration (MIA) values of sediment and rock samples (in \%).

\begin{tabular}{|c|c|c|c|c|c|c|c|c|c|c|c|c|c|c|c|c|c|}
\hline & $\mathrm{SiO}_{2}$ & $\mathrm{Fe}_{2} \mathrm{O}_{3}$ & $\mathrm{Al}_{2} \mathrm{O}_{3}$ & $\mathrm{MnO}$ & $\mathrm{CaO}$ & $\mathrm{MgO}$ & $\mathrm{Na}_{2} \mathrm{O}$ & $\mathrm{K}_{2} \mathrm{O}$ & $\mathrm{P}_{2} \mathrm{O}_{5}$ & $\mathrm{TiO}_{2}$ & LOI & Total & TOC & ICV & CIA & PIA & MIA \\
\hline PFC1 & 53.87 & 7.58 & 15.38 & 0.14 & 5.76 & 2.89 & 5.88 & 0.93 & 0.08 & 0.61 & 6.90 & 100.02 & 0.47 & 1.55 & 42.10 & 41.64 & 41.53 \\
\hline PFC2 & 52.23 & 8.39 & 16.46 & 0.15 & 6.52 & 3.20 & 5.91 & 0.70 & 0.09 & 0.67 & 5.70 & 100.01 & 0.14 & 1.55 & 42.43 & 42.12 & 41.76 \\
\hline PFC3 & 54.89 & 7.52 & 15.29 & 0.14 & 5.85 & 3.06 & 5.90 & 0.89 & 0.09 & 0.62 & 5.80 & 100.03 & 0.56 & 1.57 & 41.78 & 41.32 & 40.89 \\
\hline PFC5 & 53.39 & 7.12 & 15.68 & 0.13 & 5.75 & 3.02 & 6.65 & 0.68 & 0.08 & 0.58 & 6.90 & 99.99 & 0.16 & 1.53 & 41.47 & 41.12 & 40.45 \\
\hline PFC6 & 53.58 & 6.78 & 15.83 & 0.11 & 5.39 & 2.95 & 6.48 & 0.74 & 0.07 & 0.54 & 7.50 & 99.96 & 0.17 & 1.45 & 42.68 & 42.35 & 41.24 \\
\hline PFC7 & 54.44 & 7.16 & 15.64 & 0.14 & 5.53 & 2.93 & 6.35 & 0.96 & 0.11 & 0.65 & 6.10 & 100.01 & 0.51 & 1.52 & 42.06 & 41.59 & 41.11 \\
\hline UL2 & 58.35 & 7.79 & 15.27 & 0.17 & 3.93 & 1.83 & 4.08 & 1.21 & 0.14 & 0.81 & 6.40 & 99.99 & 0.33 & 1.30 & 50.17 & 50.18 & 50.56 \\
\hline UL3 & 58.80 & 7.48 & 14.95 & 0.16 & 3.71 & 1.80 & 3.77 & 1.23 & 0.12 & 0.81 & 7.20 & 100.02 & 0.83 & 1.27 & 51.15 & 51.26 & 51.16 \\
\hline UL4 & 58.45 & 7.81 & 15.32 & 0.17 & 3.95 & 2.02 & 3.50 & 1.24 & 0.11 & 0.88 & 6.60 & 100.04 & 0.46 & 1.28 & 51.75 & 51.93 & 51.15 \\
\hline UL5 & 59.99 & 7.65 & 15.04 & 0.16 & 3.64 & 1.84 & 3.56 & 1.19 & 0.12 & 0.81 & 6.00 & 100.01 & 0.08 & 1.25 & 52.22 & 52.43 & 51.96 \\
\hline UL6 & 58.01 & 9.14 & 15.57 & 0.18 & 3.61 & 1.82 & 3.78 & 1.27 & 0.15 & 0.91 & 5.60 & 100.03 & 0.22 & 1.33 & 52.38 & 52.62 & 53.29 \\
\hline Average & 58.01 & 8.32 & 15.34 & 0.17 & 3.85 & 1.92 & 4.11 & 1.19 & 0.14 & 0.87 & 6.12 & 100.02 & 0.33 & 1.33 & 50.62 & 50.71 & 51.01 \\
\hline ML5 & 57.34 & 7.71 & 15.46 & 0.19 & 4.91 & 1.82 & 4.26 & 1.43 & 0.15 & 0.80 & 5.90 & 99.97 & 0.60 & 1.37 & 46.93 & 46.61 & 47.99 \\
\hline Average & 57.89 & 7.54 & 15.23 & 0.17 & 4.59 & 1.97 & 3.89 & 1.43 & 0.14 & 0.80 & 6.34 & 100.00 & 0.44 & 1.34 & 48.40 & 48.23 & 48.56 \\
\hline $\mathrm{MCl}$ & 56.37 & 9.28 & 15.25 & 0.20 & 4.83 & 2.20 & 4.76 & 1.19 & 0.17 & 0.87 & 4.90 & 100.01 & 0.14 & 1.53 & 46.00 & 45.66 & 47.43 \\
\hline $\mathrm{MC} 2$ & 54.64 & 8.89 & 15.21 & 0.18 & 4.65 & 2.85 & 4.17 & 0.77 & 0.14 & 0.85 & 7.70 & 100.05 & 0.17 & 1.47 & 48.50 & 48.42 & 47.21 \\
\hline Average & 55.51 & 9.09 & 15.23 & 0.19 & 4.74 & 2.53 & 4.47 & 0.98 & 0.16 & 0.86 & 6.30 & 100.03 & 0.16 & 1.50 & 47.25 & 47.04 & 47.32 \\
\hline $\mathrm{UC1}$ & 57.08 & 8.29 & 15.38 & 0.19 & 4.86 & 2.14 & 4.43 & 1.45 & 0.16 & 0.80 & 5.20 & 99.97 & 0.23 & 1.44 & 46.50 & 46.13 & 47.22 \\
\hline $\mathrm{UC2}$ & 57.30 & 8.26 & 15.63 & 0.15 & 3.86 & 2.40 & 2.21 & 1.32 & 0.10 & 0.85 & 7.90 & 99.98 & 0.29 & 1.22 & 56.40 & 57.13 & 53.52 \\
\hline Average & 57.19 & 8.28 & 15.51 & 0.17 & 4.36 & 2.27 & 3.32 & 1.39 & 0.13 & 0.83 & 6.55 & 99.98 & 0.26 & 1.33 & 51.45 & 51.63 & 50.37 \\
\hline IV1 & 53.09 & 8.64 & 16.36 & 0.17 & 6.17 & 2.77 & 6.01 & 0.53 & 0.09 & 0.67 & 5.50 & 100.00 & 0.15 & 1.53 & 43.01 & 42.79 & 43.26 \\
\hline IV2 & 52.99 & 8.62 & 17.16 & 0.15 & 7.11 & 3.45 & 4.24 & 0.71 & 0.07 & 0.68 & 4.80 & 99.97 & 0.73 & 1.45 & 45.36 & 45.16 & 43.53 \\
\hline Average & 53.04 & 8.63 & 16.76 & 0.16 & 6.64 & 3.11 & 5.13 & 0.62 & 0.08 & 0.68 & 5.15 & 99.99 & 0.44 & 1.49 & 44.18 & 43.98 & 43.40 \\
\hline EG1 & 53.38 & 7.95 & 15.66 & 0.15 & 6.00 & 2.82 & 5.67 & 0.49 & 0.07 & 0.65 & 7.20 & 100.04 & 1.14 & 1.51 & 42.99 & 42.78 & 42.63 \\
\hline
\end{tabular}

EG = Ecology Glacier Creek; IV = Italian Valley Creek; MC = Mud Creek; ML = Mud Lake; n.a. = not analysed; PFC = Petrified Forest Creek; $\mathrm{TC}=$ Tower Creek; UC = Upper Creek; UL = Upper Lake; VC = Vanishing Creek.

$53 \%$ of total anions in the outflow water (MC) of ML and in the $\mathrm{VC}$ stream water are composed of $\mathrm{HCO}_{3}^{-}$, respectively. In contrast, stream waters showed the lowest $\mathrm{HCO}_{3}^{-}$values, accounting for $<40 \%$ of the total anions, particularly in the PFC (average of 36\%) and TC (37\%) streams and the EG (38\%) meltwater. Except for the ML (average of 24\%), its outflow waters (MC, 29\%) and the $\mathrm{VC}(47 \%)$ stream, $\mathrm{Cl}^{-}$is the most dominant anion, with a concentration ranging from 0.338 to $1.156 \mathrm{mmol} / \mathrm{l}$. $\mathrm{SO}_{4}^{2-}$ ranges from 0.010 to $0.281 \mathrm{mmol} / \mathrm{l}$, and the highest values occur in the $\mathrm{UL}$ (Table I). $\mathrm{NO}_{3}^{-}$is below the detection limits for the majority of samples. The molar sum of the two anions $\left(\mathrm{SO}_{4}^{2-}, \mathrm{Cl}^{-}\right)$is highly dependent on the sample, accounting for between $<35 \%$ and $>65 \%$ of the total anions, where $\mathrm{SO}_{4}^{2-}$ alone accounts for an average of $7 \%$. Dissolved silica is mainly derived from silicate weathering and shows fairly uniform values across the study area. The mean concentration of dissolved silica is $0.049 \mathrm{mmol} / \mathrm{l}$ in the lakes and $0.058 \mathrm{mmol} / 1$ in the lake-associated outflow waters, while its values are 0.085 and $0.045 \mathrm{mmol} / \mathrm{l}$ in the PFC and IV stream waters, respectively. Frontline meltwaters (EG and VC) have dissolved silica contents ranging from 0.030 to $0.10 \mathrm{mmol} / \mathrm{l}$. Among the water catchment areas, PFC showed the highest Si content, followed by ML and UL. The lowest $\mathrm{Si}$ values were detected in the IV2 and EG2 waters obtained from frontline meltwaters. All water samples display low $\mathrm{Fe}$ and $\mathrm{Al}$ concentrations in accordance with their slightly alkaline characteristics.

Based on the major cation and anion characteristics of all water samples, surface waters of the western shore of 

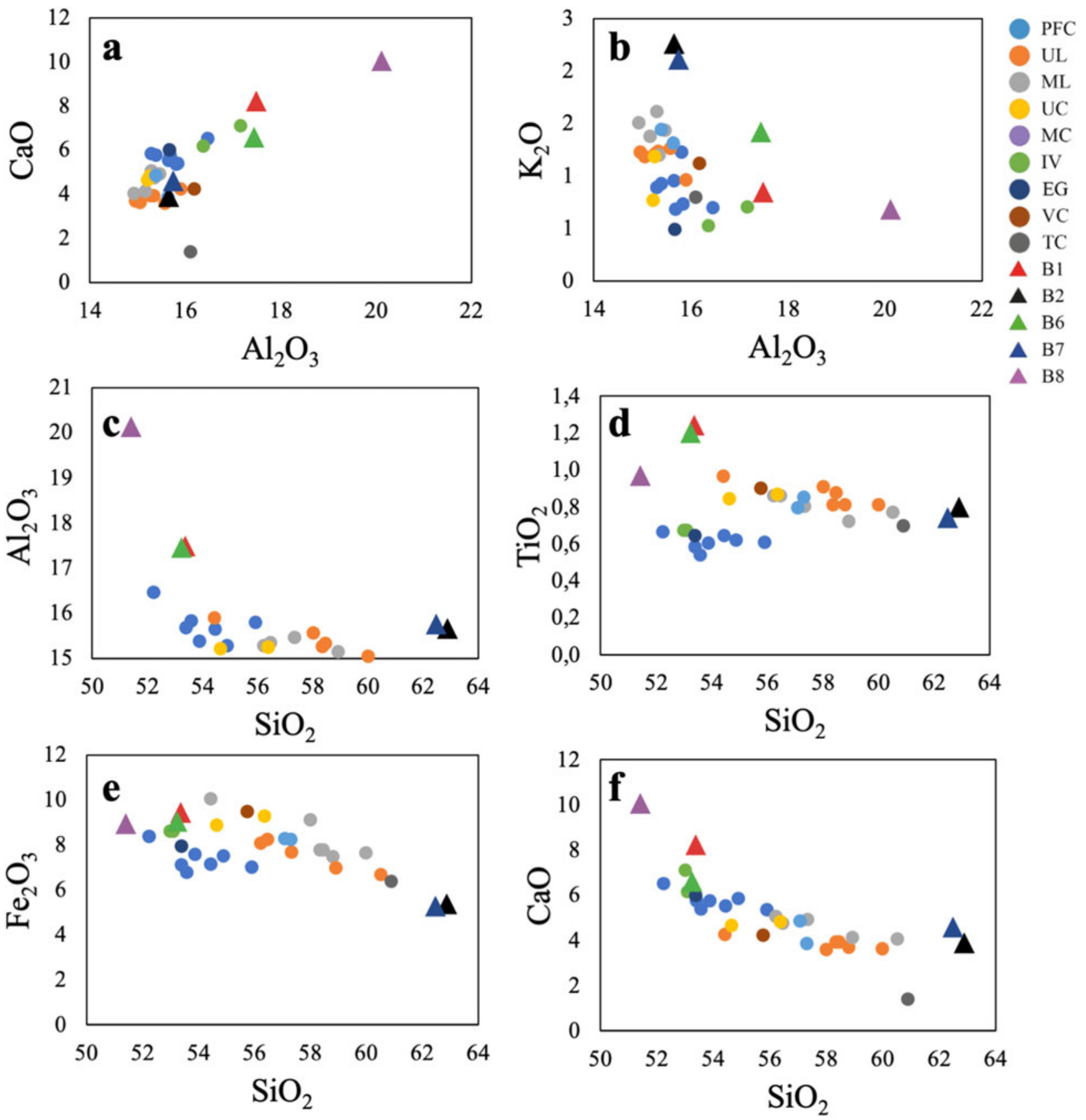

Fig. 4. Bivariate plots of the oxides of $\mathrm{CaO}$. a. \& b. $\mathrm{K}_{2} \mathrm{O}$ vs $\mathrm{Al}_{2} \mathrm{O}_{3}$ and c. $-\mathbf{f} . \mathrm{Al}_{2} \mathrm{O}_{3} \cdot \mathrm{TiO}_{2} \cdot \mathrm{Fe}_{2} \mathrm{O}_{3} \cdot \mathrm{CaO}$ vs $\mathrm{SiO}$ in the sediment and bedrock from the western part of Admiralty Bay. $\mathrm{EG}=$ Ecology Glacier Creek; IV = Italian Valley Creek; $\mathrm{MC}=\mathrm{Mud} \mathrm{Creek}$; $\mathrm{ML}=\mathrm{Mud}$ Lake; PFC = Petrified Forest Creek; TC = Tower Creek; UC = Upper Creek; UL = Upper Lake; VC = Vanishing Creek.

Admiralty Bay can be mainly categorized into two groups as sodium chloride-rich and sodium bicarbonate-rich waters, except for ML, which indicates a mixed type due to its plotting more closely to the bicarbonate end of the spectrum (Fig. 3).

\section{Mineralogy and geochemistry of bedrocks and sediments}

Mineralogical identifications of B2, B3 and B7 bedrocks, collected from in the vicinity of Ezcurra Inlet in the north-west of Admiralty Bay, revealed the presence of andesine, clinopyroxene, magnetite and augite, while albite, mordenite, magnetite, titanomagnetite and vermiculite were present in $\mathrm{B} 1, \mathrm{~B} 5, \mathrm{~B} 6, \mathrm{~B} 8, \mathrm{~B} 9$ and $\mathrm{B} 10$ rock samples (Fig. 2). Minor amounts of glassy material were particularly observed in B2, B3 and B7 rock samples. Altered rock samples B4, B11 and B12 comprise albite as plagioclase, unidentified zeolites, augite, natrolite, hematite, heulandite, spangolite and quartz (Fig. S3). 


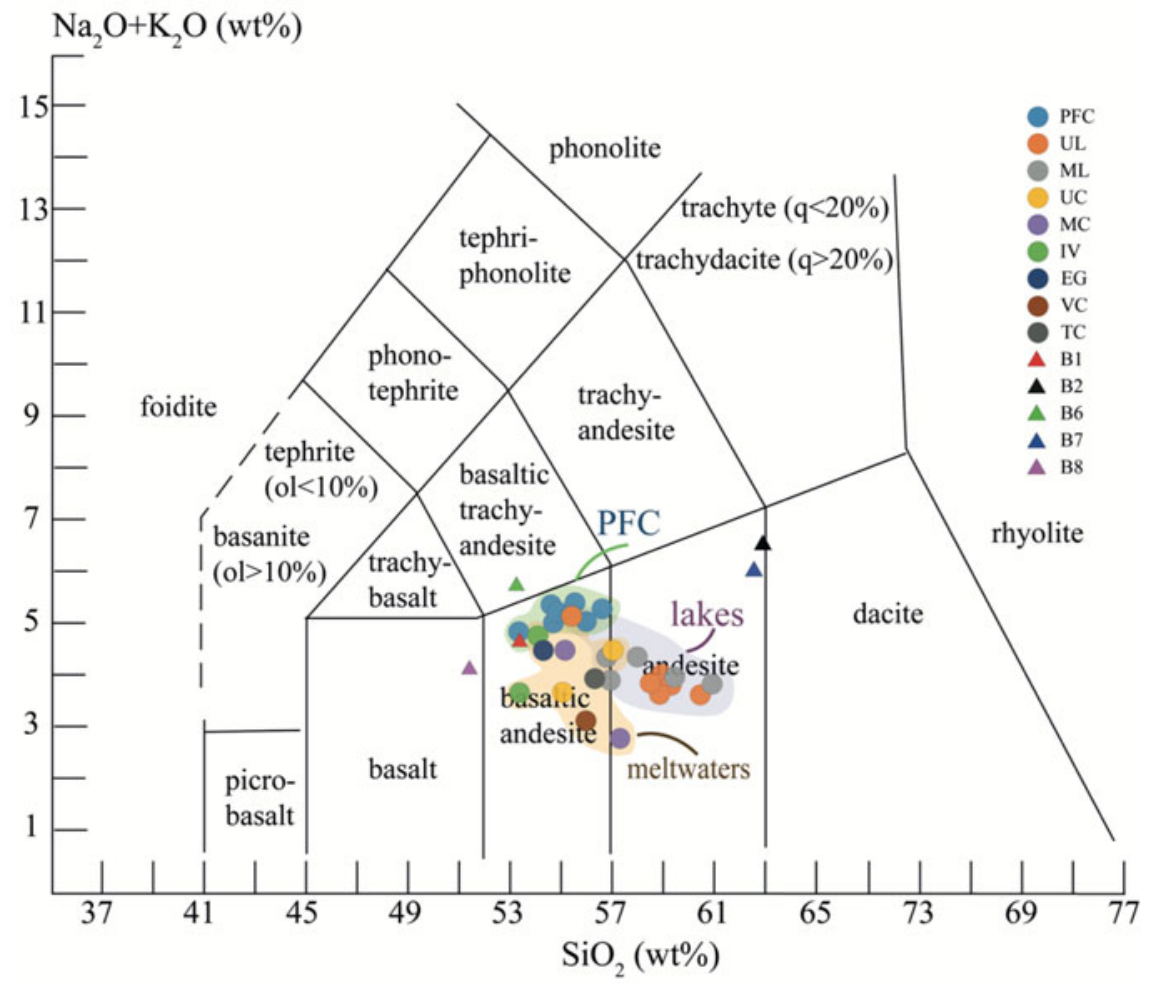

Fig. 5. Comparison of the sediment samples with the bedrocks in the total alkali-silica diagram (Le Bas et al. 1986).

$\mathrm{EG}=$ Ecology Glacier Creek; $\mathrm{IV}=$ Italian Valley Creek; $\mathrm{MC}=$ Mud Creek; $\mathrm{ML}=$ Mud Lake; ol = olivine; $\mathrm{PFC}=$ Petrified Forest Creek; $\mathrm{q}=$ quartz; $\mathrm{TC}=$ Tower Creek; UC $=$ Upper Creek; $\mathrm{UL}=$ Upper Lake; $\mathrm{VC}=$ Vanishing Creek.
The whole-rock geochemistry analyses show that the bedrocks (mafic volcanic rocks) are basalt-basaltic andesite in composition (Table II). Consistently, the $\mathrm{SiO}_{2}$ contents of the bedrocks range from $51.43 \%$ to $62.90 \%$, implying a mafic to intermediate nature of the bedrocks in the studied area. In general, the rock samples have high $\mathrm{Al}_{2} \mathrm{O}_{3}$ contents ranging from $15.66 \%$ to $20.12 \%$. As expected, a good negative correlation exists between $\mathrm{SiO}_{2}$ and $\quad \mathrm{Al}_{2} \mathrm{O}_{3} \quad(R=-0.88), \quad \mathrm{Fe}_{2} \mathrm{O}_{3(\mathrm{~T})} \quad(R=-0.97), \quad \mathrm{CaO}$ $(R=-0.92), \quad \mathrm{MgO} \quad(R=-0.95) \quad$ and $\quad \mathrm{TiO}_{2}$ contents $(R=-0.66)$ in the bedrocks. In contrast, there are slight and strong positive correlations, respectively, between $\mathrm{SiO}_{2}$ and $\mathrm{Na}_{2} \mathrm{O}(R=0.44)$ and $\mathrm{K}_{2} \mathrm{O}$ contents $(R=0.95)$ (Table II).

Loss on ignition (LOI) values range from $4.8 \%$ to $7.9 \%$, indicating the presence of various amounts of carbonate, organic matter, phyllosilicates and, to a lesser extent, amphiboles. Major oxides diagrams of $\mathrm{SiO}_{2}$ vs $\mathrm{Al}_{2} \mathrm{O}_{3}$ and $\mathrm{SiO}_{2}$ vs $\mathrm{CaO}$ indicate slight compositional variability among the samples. For example, $\mathrm{SiO}_{2}$ contents range from $52.2 \%$ to $60.9 \%$ and $\mathrm{Al}_{2} \mathrm{O}_{3}$ contents range from $14.9 \%$ to $17.1 \%$. As observed in the rocks, a good negative correlation exists between $\mathrm{SiO}_{2}$ and $\mathrm{Al}_{2} \mathrm{O}_{3}$ in the ML $(R=-0.8)$ and UL $(R=-0.8)$ sediments, and a moderate negative correlation exists in the PFC sediments $(R=-0.4)$. Consistently, there are good negative correlations between $\mathrm{SiO}_{2}$ and $\mathrm{Fe}_{2} \mathrm{O}_{3}$ in the $\mathrm{ML}$ $(R=-0.8)$ and UL sediments $(R=-0.95)$ and a weak negative correlation in the PFC sediments $(R=-0.3)$ (Fig. 4). Although there are no clear subdivisions between sediment samples based on bedrocks, the cross-plots of $\mathrm{SiO}_{2}$ vs $\mathrm{CaO}, \mathrm{Al}_{2} \mathrm{O}_{3}$ vs $\mathrm{K}_{2} \mathrm{O}$ and $\mathrm{Al}_{2} \mathrm{O}_{3}$ vs $\mathrm{CaO}$ suggest that the lakes sediments dominantly originated from andesite, while the stream channel sediments are both from andesite and basaltic-andesine, as revealed by the total alkali-silica diagram (Fig. 5) (Le Bas et al. 1986). Overall, the major element concentrations of all sediments followed the order of $\mathrm{Si}>\mathrm{Al}>\mathrm{Fe}>$ $\mathrm{Ca}=\mathrm{Na}>\mathrm{Mg}>\mathrm{K}$.

The mineralogical compositions of all sediments (bulk) comprise predominantly plagioclases as either albite or anorthite accompanied by quartz, zeolite group minerals (stilbite, laumontite, gonnardite and natrolite) and clay minerals (undifferentiated smectites and vermiculite). Magnetite and occasionally calcite were present. The comparison of sediment mineralogy reveals some differences in particular zeolite group minerals. For example, a wide range of zeolite minerals (stilbite, laumontite, gonnardite and natrolite) were only identified in the PFC sediments throughout the flow paths from source to sink with almost identical mineral compositions (Fig. S4). The bulk mineral compositions of ML and UL are similar to those of their stream channel sediments (MC and UC), comprising predominantly plagioclase and quartz as suggested by the intensity of the peaks. Anorthite was identified only in the ML sediments, while zeolite minerals of laumontite and faujasite were only present in the UL sediments. As suggested by the peak intensity, clay minerals comprise a minor part of the 
Table III. Average trace element and rare earth element (REE) concentrations ( $p p m$ ) of the bedrocks and sediments of the western part of Admiralty Bay.

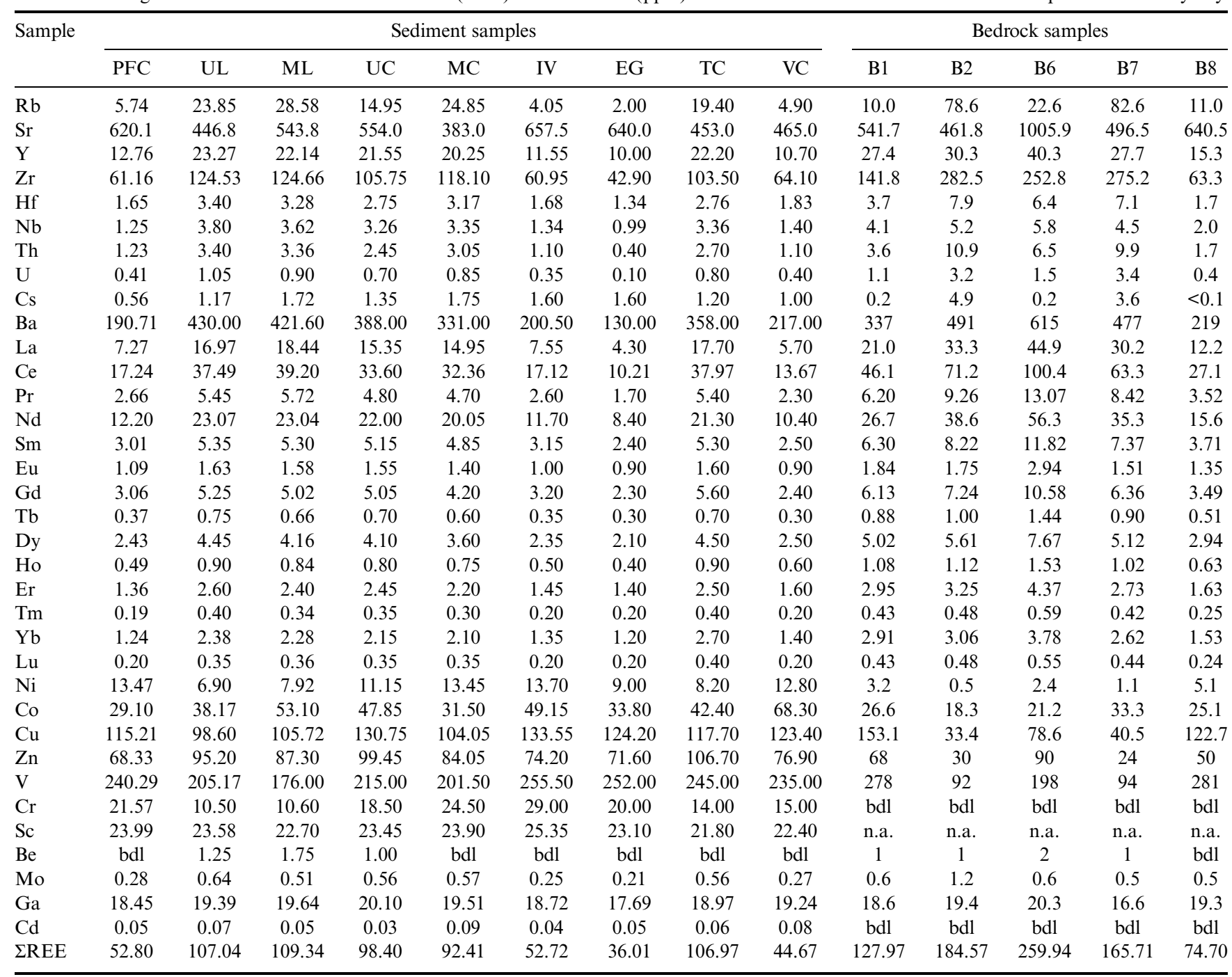

bdl = below detection limits; EC = electrical conductivity; EG = Ecology Glacier Creek; IV = Italian Valley Creek; MC = Mud Creek; ML = Mud Lake; n.a. = not analysed; PFC = Petrified Forest Creek; TC = Tower Creek; UC = Upper Creek; UL = Upper Lake; VC = Vanishing Creek.

sediments. The broad carbon peak occasionally observed in the PFC sediments is attributed to the remnants of wood fragments from the vegetated, pre-glaciation period (Mozer 2012).

The TOC content of the sediments showed great variability among the samples, ranging from $0.01 \%$ to $1.14 \%$ with an average value of $0.35 \%$. Relative to the stream sediments, the lake sediments have slightly higher TOC contents (e.g. UL3 and ML4; Table II). In contrast to the stream sediments, a strong positive correlation exists between the TOC and LOI contents of the UL $(R=0.76)$, indicating that LOI values represent the organic matter content, while ML sediments exhibiting a strong negative correlation $(R=-0.89)$ probably represent other sources, such as inorganic carbon and/or hydrated minerals (e.g. clays).

\section{Trace and rare earth element distributions}

The trace element and rare earth element (REE) compositions of the sediments and the bedrocks are presented in Table III. The average concentrations of $\mathrm{Rb}, \mathrm{Sr}$ and $\mathrm{Ba}$ range from 10.0 (B1) to 82.6 (B7) ppm, from 461.8 (B2) to 1005.6 (B6) ppm and from 219 (B8) to 615 (B6) $\mathrm{ppm}$ in the bedrocks, respectively. In the sediments, $\mathrm{Rb}$ ranges from 2.0 (EG) to $28.58 \mathrm{ppm}(\mathrm{ML})$, $\mathrm{Sr}$ from 383.0 (MC) to $657.5 \mathrm{ppm}$ (IV) and Ba from 130 (EG) to $430 \mathrm{ppm}$ (UL). There exists a clear correlation between $\mathrm{SiO}_{2} \mathrm{wt} \%$ and trace elements, as presented in Fig. 6. $\mathrm{Ba}, \mathrm{Zr}, \mathrm{La}, \mathrm{Ce}$ and, to a lesser degree, $\mathrm{U}$ and $\mathrm{Th}$ positively correlate with increasing $\mathrm{SiO}_{2}$ contents, whereas $\mathrm{V}, \mathrm{Ni}, \mathrm{Cu}, \mathrm{Zn}, \mathrm{Sc}$ and $\mathrm{Sr}$ correlate negatively. A significant increase in $\mathrm{Pb}$ contents of the sediments relative to the bedrocks is evident. Ocean island basalt-normalized 

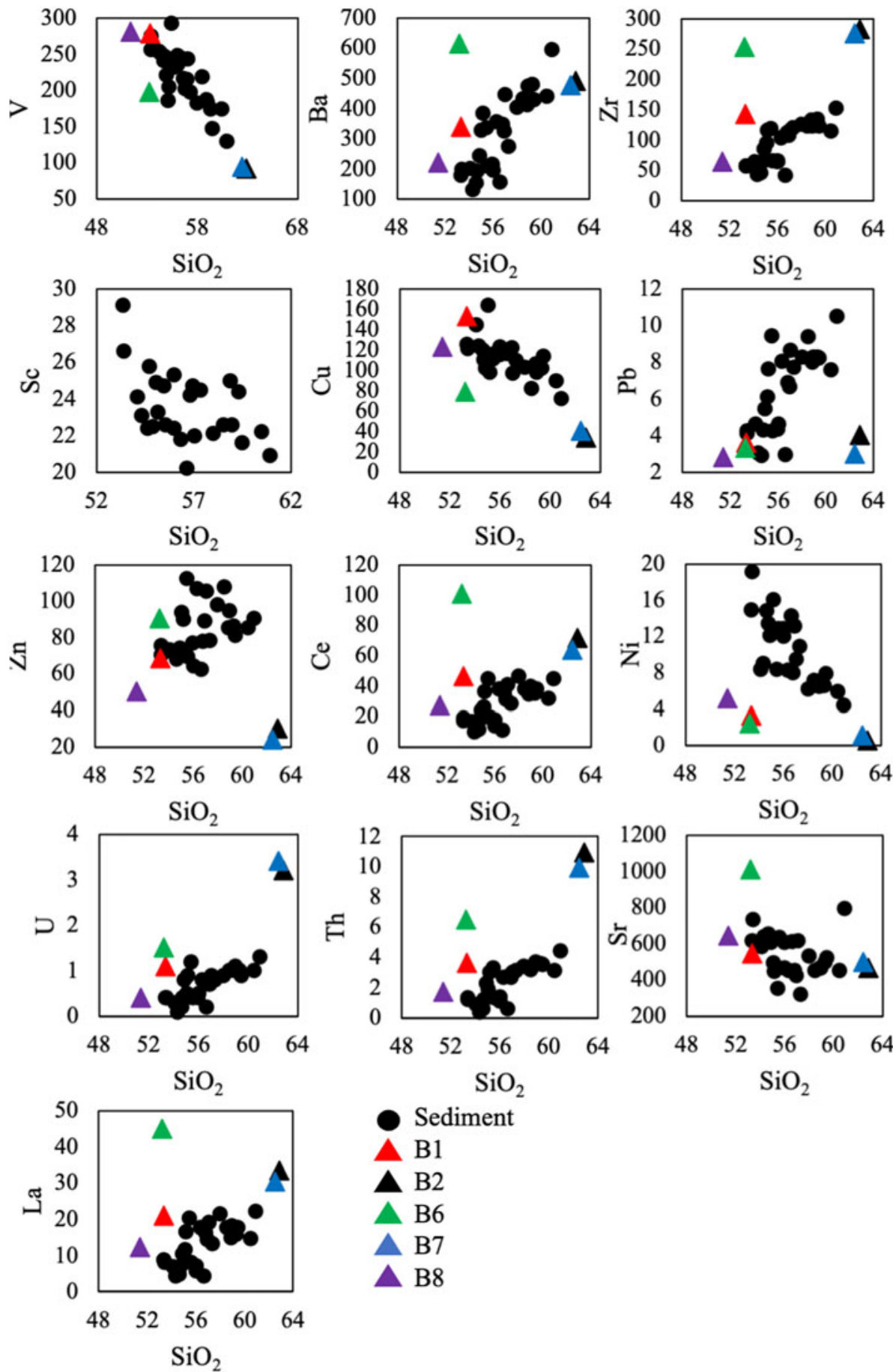

\section{Sediment}

$\triangle \mathrm{B} 1$

$\Delta \mathrm{B} 2$

$\triangle \mathrm{B} 6$

$\triangle \mathrm{B} 7$

$\triangle \mathrm{B} 8$

Fig. 6. Correlation plots of the trace elements (ppm) against $\mathrm{SiO}_{2}(\mathrm{wt} \%)$.

REE distribution patterns of the sediments and the bedrock samples are presented in Fig. 7.

\section{Grain size distribution}

The grain size distribution of the particles varied among the stream channel, lake and lake-associated outflow sediments. In contrast to the lake sediments, the majority of the stream channel sediments are sand-sized ( $2 \mathrm{~mm}$; Fig. 8). In the stream channel (PFC) and the lake outflow sediments (MC and UC), the fine fraction sediments (clay to silt size; $<63 \mu \mathrm{m}$ ) comprise $<0.4 \%$ of the bulk sediments. Consistently, outflow stream sediments (MC and UC2) contain dominantly granule size materials ( $>2 \mathrm{~mm}$ ), ranging from $53 \%$ to $60 \%$, and 


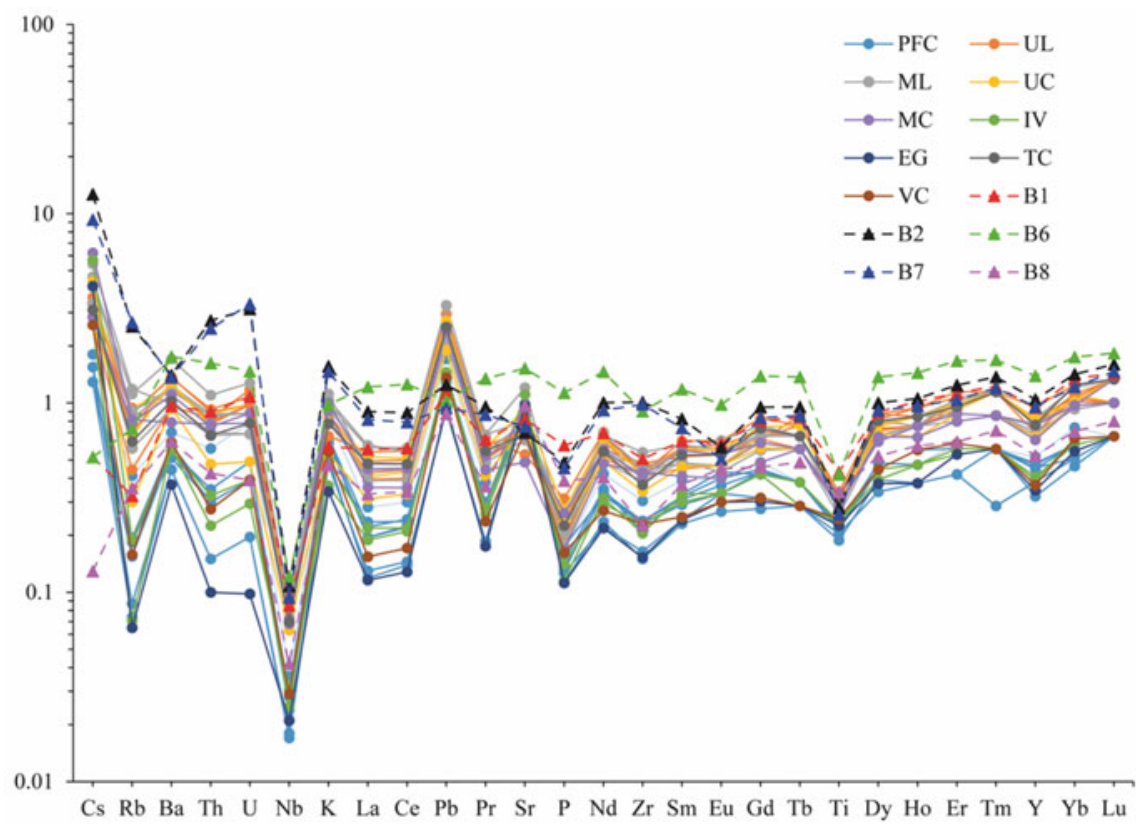

Fig. 7. Ocean island basalt-normalized rare earth element distribution patterns of sediments and bedrocks of the western part of Admiralty Bay (Sun \& McDonough 1989). EG = Ecology Glacier Creek; IV = Italian Valley Creek; $\mathrm{MC}=$ Mud Creek; ML = Mud Lake; $\mathrm{PFC}=$ Petrified Forest Creek; $\mathrm{TC}=$ Tower Creek; UC $=$ Upper Creek; $\mathrm{UL}=$ Upper Lake; $\mathrm{VC}=$ Vanishing Creek. the remainder is composed of mostly coarse to very coarse sand (from $33 \%$ to $38 \%$ ). The lake sediments are composed of very fine to fine size sand fractions $(50 \%$ in the ML and $26 \%$ in the UL) along with $>3 \%$ and $1 \%$ clay to silt size fractions in the ML and UL sediments, respectively (Table $\mathrm{S} 2$ ).

The distribution of particles size $<2 \mathrm{~mm}$ showed that the majority of the stream channel sediments consist of materials with a size of $>63 \mu \mathrm{m}(80 \% \pm 8 \%)$. The lake and the lake-associated outflow stream sediments hold the largest amount of $<4 \mu \mathrm{m}$-sized particles (from $9 \%$ to $18 \%$ ) and correspondingly fewer $>63 \mu \mathrm{m}$-sized fractions (from $45 \%$ to $55 \%$ ) (Table S2).

\section{Discussion}

\section{Sources of major ions as inferred from water chemistry}

The relative contributions of water-rock interactions, atmospheric deposition and evaporation-induced crystallization to the surface water chemistry of the western part of Admiralty Bay were evaluated. The surface waters of the western part of Admiralty Bay are classified into two groups: $\mathrm{Na}^{+}-\mathrm{CI}^{-}$and $\mathrm{Na}^{+}-\mathrm{HCO}_{3}^{-}$ (Fig. 3). $\mathrm{Na}^{+}$and $\mathrm{CI}^{-}$-normalized Gibbs plots revealed that the majority of water samples were predominantly plotted in the atmospheric precipitation (marine aerosols) area with a few samples indicating rock weathering, but not by evaporation (Fig. 9). Our results accord well with those obtained from Thomas Point Oasis, Admiralty Bay, and Potter Peninsula on KGI, as well as those of Nedzarek et al. (2015). As in the current study, the authors showed that various freshwater bodies were dominated by $\mathrm{Na}^{+}$and $\mathrm{CI}^{-}$ions (Nedzarek et al.
2015, Szopińska et al. 2018). Compared to the lake waters, the stream water samples, particularly those obtained from the frontline of meltwaters (EG and VC) in close proximity to the glacial zone (TC), clearly reflect atmospheric precipitation (marine aerosols or sea spray) as the main elemental input into water (Fig. 9).

In Fig. 10a, by comparing with lake waters (ML and $\mathrm{UL})$, the majority of the stream data points closely plot a 1:1 trend line, suggesting that atmospheric deposition (marine aerosols) is a significant source, particularly for the stream waters. Conversely, the majority of the lake water data deviate from and scatter below the 1:1 trend line, suggesting $\mathrm{Na}^{+}$enrichment. Therefore, the excess $\mathrm{Na}^{+}$and $\mathrm{K}^{+}$to $\mathrm{Cl}^{-}$should be derived from sodium and potassium aluminosilicate weathering. It is particularly noticeable that the $\mathrm{Na}^{+} / \mathrm{Cl}^{-}$ratios of the lake waters and associated outflow waters are significantly greater than those of the stream waters, further implying the significance of water-rock retention time for the intensity of chemical weathering (Table IV). Figure 10b shows that $\mathrm{Ca}^{2+}$ and $\mathrm{Mg}^{2+}$ are less relevant to sulphate sources, except that a minor contribution of sulphate to $\mathrm{MC1}$ and UL2 may be attributed to atmospheric deposition or localized sulphate-bearing secondary phases. In the $\mathrm{Ca}^{2+}+\mathrm{Mg}^{2+}$ vs $\mathrm{HCO}_{3}^{-}$scatter diagram, the ionic compositions of ML, its outflow waters (MC) and a few points from UL fall above the 1:1 trend line. Compared to the stream waters, a significant increase in the bicarbonate trend of the lake waters, irrespective of $\mathrm{Ca}^{2+}$ and $\mathrm{Mg}^{2+}$ contents, is a good indication for weathering of prevailing Na-rich silicate rocks in the water catchment areas (Figs S3 \& S4). Accordingly, excess $\mathrm{Ca}^{2}$ ${ }^{+}+\mathrm{Mg}^{2+}$ to $\mathrm{HCO}_{3}^{-}$is a good indication of atmospheric 


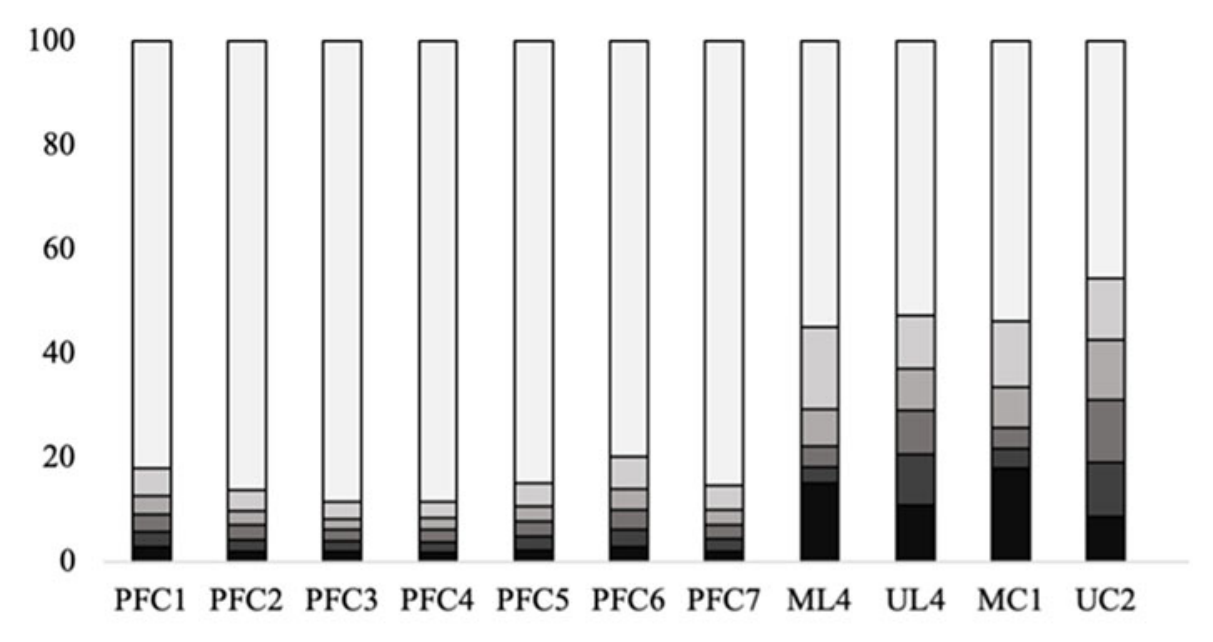

घ $<4 \mu \mathrm{m} \square 4-8 \mu \mathrm{m} \quad \square 8-16 \mu \mathrm{m} \quad \square 16-31 \mu \mathrm{m} \quad \square 31-63 \mu \mathrm{m} \quad \square 63 \mu \mathrm{m}-2 \mathrm{~mm}$

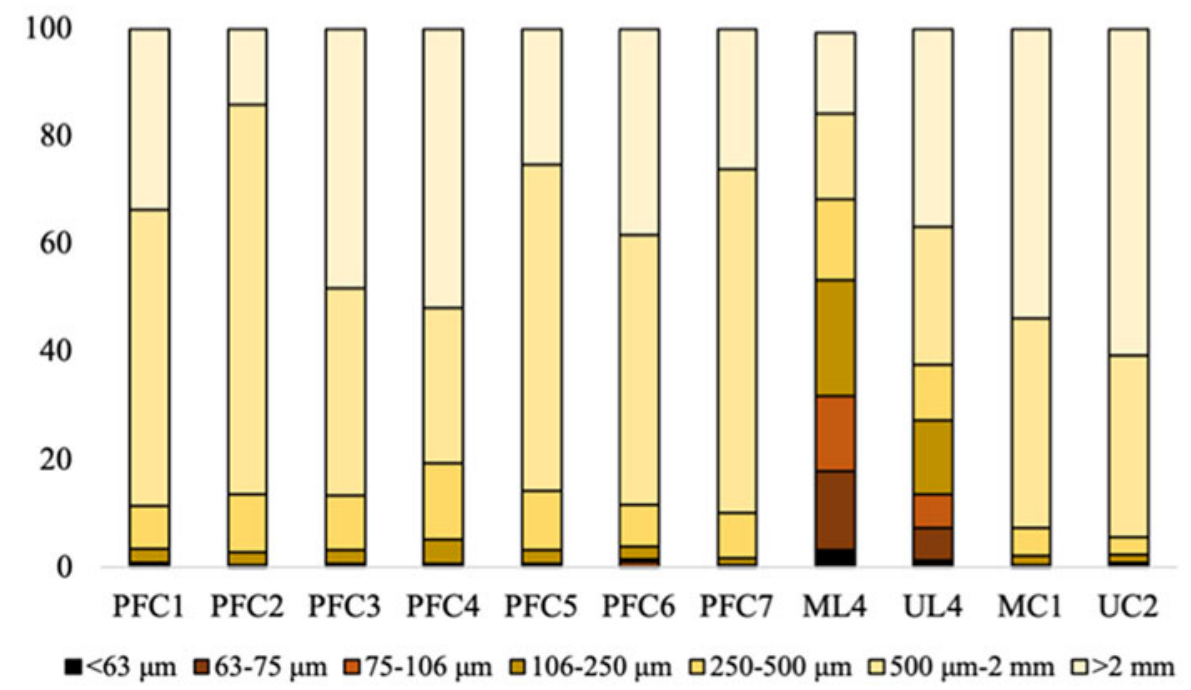

Fig. 8. Grain size distribution of selected sediments. Results of sieve analysis; weight in percentages. $M C=$ Mud Creek; $M L=M u d$ Lake; PFC = Petrified Forest Creek; UC = Upper Creek; UL = Upper Lake.

precipitation. In fact, a strong correlation exists, particularly in the stream waters, between $\mathrm{Mg}^{2+}$ and $\mathrm{CI}^{-}$ions (e.g. PFC, $R=0.94$; UL, $R=0.91$ ), further implying an atmospheric origin for the $\mathrm{Mg}^{2+}$ ions. In order to further evaluate the contributions of atmospheric sources to the major ions of surface waters, we estimated the highest chloride concentration from atmospheric input to be $1.05 \mathrm{mmol} / \mathrm{l}$ (average of the EG samples). This estimation is based on the samples (EG) that show the highest atmospheric input as revealed by Gibbs plots (Fig. 9). Then, the relative contributions of $\mathrm{Na}^{+}$ions released by silicate weathering can be evaluated, as the $1: 1$ ratio of $\mathrm{Na}^{+} / \mathrm{Cl}^{-}$is attributed to salt dissolution (Elango \& Kannan 2007). This estimate may carry some uncertainties regarding the actual amount of atmospheric input for each sample, as atmospheric precipitation can spatially and temporarily vary. Nevertheless, the highest $\mathrm{CI}^{-}$content of water may help to confine the upper limit of atmospheric input of major ions in the studied area.

After subtraction of $\mathrm{Na}^{+}$precipitated from atmospheric input from the measured $\mathrm{Na}^{+}$, the remainder is the fraction of $\mathrm{Na}^{+}$(named as $\mathrm{Na}_{\mathrm{Si}}$ ) from silicate weathering. Figure 10d was constructed by using $\mathrm{Na}_{\mathrm{Si}}+\mathrm{K}$ vs $\mathrm{HCO}_{3}^{-}$, and it suggests that, except for lake waters, the majority of the data points imply a relatively large atmospheric input. A remarkable difference in grain sizes of the stream (PFC) and lake samples and their outflow sediments is probably an important factor in the enhanced silicate dissolution in the lakes of Admiralty Bay.

Marine aerosols determine the ionic composition of atmospheric inputs and show variation during the winter and summer seasons, mainly due to changes in the area covered by ice in Admiralty Bay. It is well demonstrated that concentrations of major ions in atmospheric inputs 

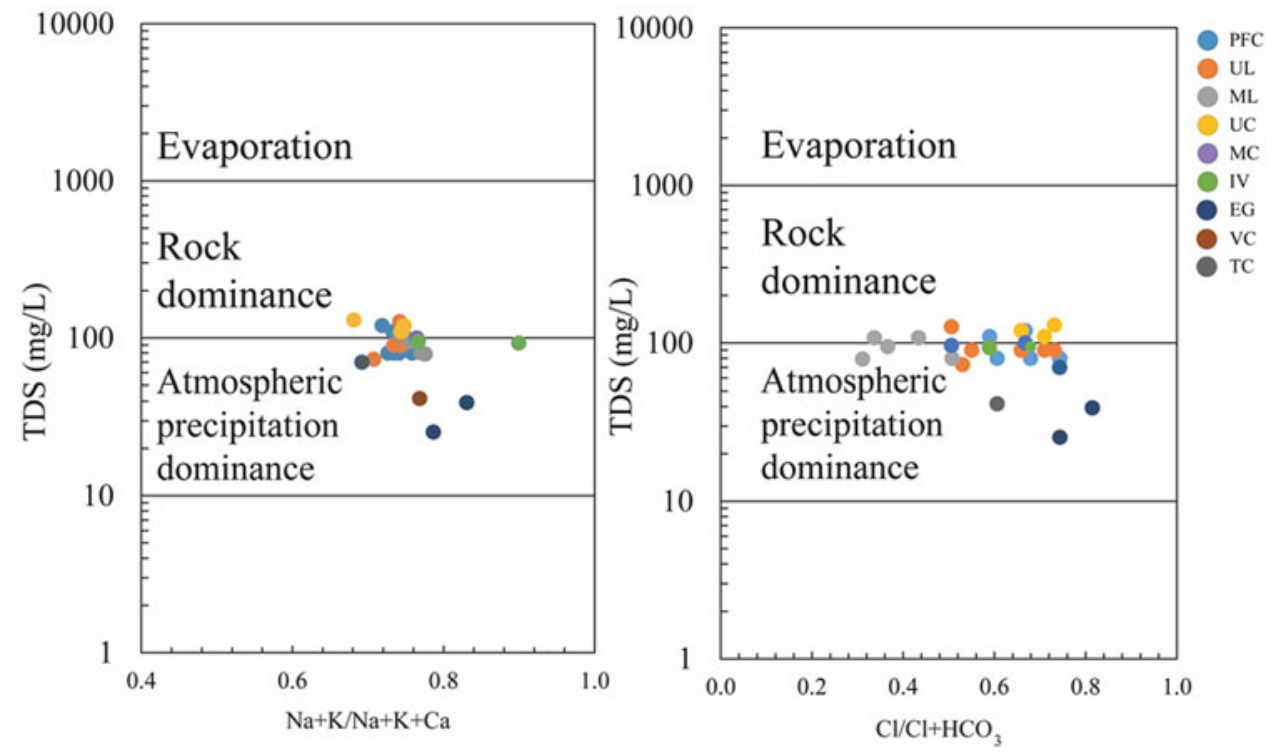

Fig. 9. Gibbs plots of stream meltwater and lake water of the western part of Admiralty Bay. EG = Ecology Glacier Creek; IV = Italian Valley Creek; MC = Mud Creek; ML = Mud Lake; PFC = Petrified Forest Creek; TC $=$ Tower Creek; TDS $=$ total dissolved solids; $\mathrm{UC}=$ Upper Creek; UL = Upper Lake; VC = Vanishing Creek.

increase during summer $(\sim 500 \mathrm{~mm} / \mathrm{year}$ for Admiralty Bay; Beyer 2002). As a result, the relative contribution of atmospheric precipitation to the major ion compositions of the streams and lakes in the Maritime Antarctic is probably more intense during summer seasons. Compared to KGI, another long-term studied region on the continent, the Antarctic Dry Valleys (ADVs), exhibit highly dissimilar atmospheric properties. The mean annual temperatures in the ADVs are between $-15^{\circ} \mathrm{C}$ and $-30^{\circ} \mathrm{C}$, and the valley bottoms reach an annual maximum of $\sim 50 \mathrm{~mm}$ precipitation (in the form of snow) water equivalent (Obryk et al. 2020). Variations in the $\mathrm{Na}^{+} / \mathrm{Cl}^{-}$ratio are frequently used to trace their sources. An $\mathrm{Na}^{+} / \mathrm{Cl}^{-}$ratio exceeding 1.7 in the surface waters of the ADVs is an indicator for the salts originated from weathering of mirabilite or feldspars (Green et al. 1988, Nedzarek 2015). Accordingly, the $\mathrm{Na}^{+} / \mathrm{Cl}^{-}$ratios of PFC samples (1.2-1.6) indicate that the salts mainly originated from atmospheric precipitation (Table IV). Consistently, as observed in the Gibbs plots, water samples from EG and IV, with the lowest $\mathrm{Na}^{+} / \mathrm{Cl}^{-}$ratios, clearly indicate that the salts originated from atmospheric deposition (Fig. 9 \& Table IV).

In contrast, the $\mathrm{Na}^{+} / \mathrm{Cl}^{-}$ratios of lake waters (ML and UL) and their outflow waters (MC and UC) did exceed 1.7, implying the weathering of silicate, mainly feldspars, as the predominant source that contributed to these salts. Similarly, the high $\mathrm{Ca}^{2+} / \mathrm{Mg}^{2+}$ ratios of the respected samples further highlight the contribution of silicate weathering to the water chemistry of the lakes and associated outflow waters.
The $\mathrm{Na}^{+} / \mathrm{Cl}^{-}$and $\mathrm{Ca}^{2+} / \mathrm{Mg}^{2+}$ ratios measured in the stream and lakes waters of Admiralty Bay are significantly higher than those measured in the previous studies on KGI (Thomas Point Oasis, KGI, $\mathrm{Na}^{+} / \mathrm{Cl}^{-}<1.15$; $\mathrm{Ca}^{2+} / \mathrm{Mg}^{2+}=0.89$ ), but they are lower than the ADVs $\left(\mathrm{Na}^{+} / \mathrm{Cl}^{-}>1.7 ; \mathrm{Ca}^{2+} / \mathrm{Mg}^{2+}=2.6-20.7\right)$ (Green et al. 1988, Nędzarek et al. 2015, Szopińska et al. 2018). The $\mathrm{Mg}^{2+} / \mathrm{Cl}^{-}$ratio of the lakes and associated waters was two times lower in comparison to the stream waters (e.g. PFC). A comparatively higher $\mathrm{Mg}^{2+} / \mathrm{Cl}^{-}$ratio indicates that $\mathrm{Mg}^{2+}$, similar to $\mathrm{Na}^{+}$and $\mathrm{Ca}^{2+}$, predominantly originated from atmospheric precipitation in the stream waters. Similarly, the low $\mathrm{Ca}^{2+} / \mathrm{Na}^{+}$ratio $(0.1-0.2)$ varied uniformly among all of the water samples, and the $\mathrm{HCO}_{3}^{-} / \mathrm{Cl}^{-}$ratio being greater in the lake samples showed that $\mathrm{Na}^{+}$and $\mathrm{CI}^{-}$are dominant ions in the stream waters, while $\mathrm{Na}^{+}$and $\mathrm{HCO}_{3}^{-}$are dominant in the lake waters. These results suggest that the ionic compositions of the stream waters in Admiralty Bay, in contrast to the lake waters, are predominantly under the influence of atmospheric precipitation occurring via evaporation and accumulation of the salts in the sediments and their subsequent washing out.

\section{Major element changes as indications of weathering degree}

Changes in the major cation contents of sediments are widely used to estimate the degree of chemical weathering (Young \& Nesbitt 1998). There are few approaches to estimating the degree of chemical weathering. The Index of Compositional Variability 

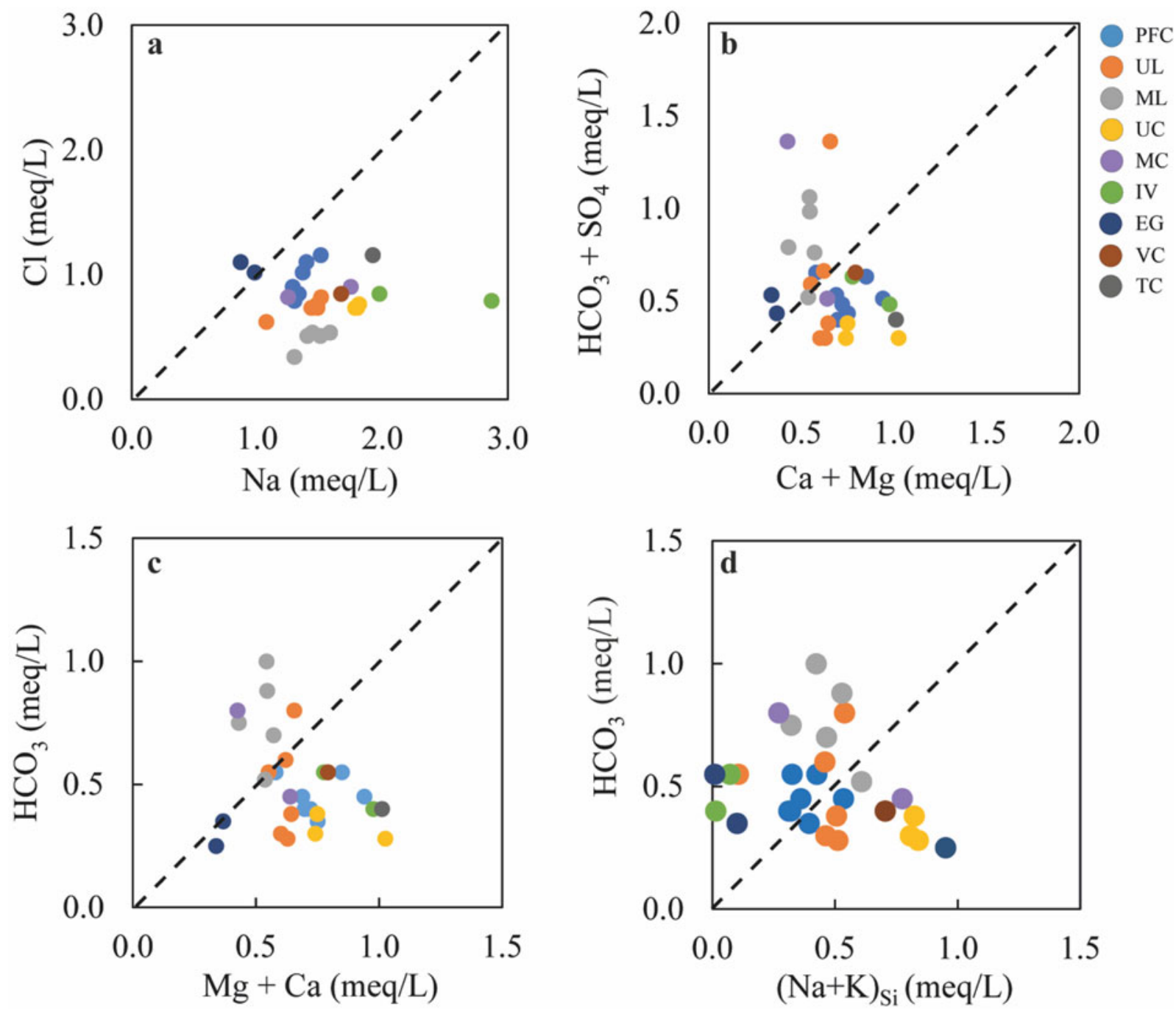

Fig. 10. Plots of a. $\mathrm{Cl}^{-}$vs $\mathrm{Na}^{+}$, b. $\left(\mathrm{HCO}_{3}^{-}+\mathrm{SO}_{4}^{2-}\right)$ vs $\left(\mathrm{Ca}^{2+}+\mathrm{Mg}^{2+}\right)$, c. $\mathrm{HCO}_{3}^{-}$vs $\left(\mathrm{Ca}^{2+}+\mathrm{Mg}^{2+}\right)$ and d. $\mathrm{HCO}_{3}^{-}$vs $(\mathrm{Na}+\mathrm{K})_{\mathrm{Si}}$. $\mathrm{EG}=$ Ecology Glacier Creek; IV = Italian Valley Creek; MC = Mud Creek; ML = Mud Lake; PFC = Petrified Forest Creek; $\mathrm{TC}=$ Tower Creek; UC = Upper Creek; UL = Upper Lake; VC = Vanishing Creek.

(ICV) is one of them (Cox et al. 1995):

$$
\begin{aligned}
\mathrm{ICV}= & \left(\mathrm{Fe}_{2} \mathrm{O}_{3}+\mathrm{K}_{2} \mathrm{O}+\mathrm{Na}_{2} \mathrm{O}+\mathrm{CaO}+\mathrm{MgO}\right. \\
& \left.+\mathrm{MnO}+\mathrm{TiO}_{2}\right) / \mathrm{Al}_{2} \mathrm{O}_{3}
\end{aligned}
$$

For example, the ICV is usually higher for the non-clay minerals due to their relatively high levels of major cations compared to $\mathrm{Al}_{2} \mathrm{O}_{3}$. Thus, sediments with a high percentage of non-clay silicate minerals or unaltered minerals will have ICV values of $>1$. In contrast, sediment samples with mostly clay minerals under intense weathering conditions should have ICV values of $<1$. Accordingly, the ICV values of the PFC sediments range from 1.44 to 1.57 , those of UL range from 1.25 to 1.55, those of ML range from 1.24 to 1.42 and those of the rest of stream channel sediments range from 0.90 to 1.53 , closely reflecting those obtained from the rocks, varying from 1.20 to 1.54 (Table II). A good positive correlation exists between the ICV values of the rocks and sediments, indicating that the sediments are dominated by non-clay minerals, thus reflecting a lower degree chemical weathering of the bedrocks. This ICV values $(>1)$ also implies that physical disintegration of the bedrocks is the major source of sediments, and chemical weathering is very minor in the region, as evidenced by the mineralogical characterization of the sediments (Fig. S4). This finding corroborates well with previous studies that also reported that chemical weathering and thus clay formation seem to be insignificant in the western part of Admiralty Bay (Nędzarek et al. 2015). Thus, physical weathering 
Table IV. Ratios of selected major elements used as source indicators for water samples.

\begin{tabular}{|c|c|c|c|c|c|}
\hline Sample & $\mathrm{Na} / \mathrm{Cl}$ & $\mathrm{Ca} / \mathrm{Mg}$ & $\mathrm{Mg} / \mathrm{Cl}$ & $\mathrm{Ca} / \mathrm{Na}$ & $\mathrm{HCO}_{3} / \mathrm{Cl}$ \\
\hline PFC1 & 1.302 & 1.71 & 0.15 & 0.197 & 0.389 \\
\hline PFC2 & 1.265 & 1.53 & 0.15 & 0.185 & 0.500 \\
\hline PFC3 & 1.421 & 2.08 & 0.13 & 0.190 & 0.443 \\
\hline PFC4 & 1.642 & 2.54 & 0.10 & 0.160 & 0.696 \\
\hline PFC5 & 1.525 & 2.07 & 0.13 & 0.182 & 0.473 \\
\hline PFC6 & 1.574 & 1.98 & 0.14 & 0.172 & 0.532 \\
\hline PFC7 & 1.344 & 1.78 & 0.13 & 0.176 & 0.345 \\
\hline UL1 & 1.731 & 4.40 & 0.08 & 0.209 & 0.886 \\
\hline UL2 & 1.945 & 4.45 & 0.08 & 0.173 & 0.368 \\
\hline UL3 & 2.018 & 5.12 & 0.07 & 0.182 & 0.518 \\
\hline UL4 & 1.959 & 4.95 & 0.07 & 0.174 & 0.409 \\
\hline UL5 & 1.953 & 4.99 & 0.07 & 0.181 & 0.818 \\
\hline UL6 & 1.846 & 4.17 & 0.08 & 0.175 & 0.978 \\
\hline ML1 & 3.830 & 6.81 & 0.08 & 0.145 & 2.216 \\
\hline ML2 & 2.687 & 7.18 & 0.07 & 0.174 & 1.306 \\
\hline ML3 & 2.954 & 7.36 & 0.06 & 0.149 & 0.970 \\
\hline ML4 & 2.961 & 7.96 & 0.06 & 0.161 & 1.733 \\
\hline ML5 & 2.756 & 7.15 & 0.07 & 0.170 & 1.970 \\
\hline $\mathrm{UC1}$ & 2.381 & 4.91 & 0.11 & 0.235 & 0.368 \\
\hline $\mathrm{UC} 2$ & 2.451 & 4.35 & 0.10 & 0.169 & 0.518 \\
\hline UC3 & 2.429 & 4.88 & 0.09 & 0.173 & 0.409 \\
\hline MC1 & 1.524 & 8.57 & 0.03 & 0.153 & 0.978 \\
\hline MC2 & 1.935 & 5.48 & 0.05 & 0.155 & 0.499 \\
\hline IV1 & 0.789 & 1.12 & 0.07 & 0.103 & 0.409 \\
\hline IV2 & 0.966 & 2.75 & 0.05 & 0.137 & 0.345 \\
\hline $\mathrm{TC}$ & 1.663 & 5.68 & 0.07 & 0.224 & 0.346 \\
\hline EG1 & 0.789 & 1.12 & 0.07 & 0.103 & 0.318 \\
\hline EG2 & 0.966 & 2.75 & 0.05 & 0.137 & 0.345 \\
\hline $\mathrm{VC}$ & 1.973 & 1.78 & 0.17 & 0.152 & 0.650 \\
\hline
\end{tabular}

$\mathrm{EG}=$ Ecology Glacier Creek; IV = Italian Valley Creek; MC = Mud Creek; ML = Mud Lake; n.a. $=$ not analysed; $\mathrm{PFC}=$ Petrified Forest Creek; $\mathrm{TC}=$ Tower Creek; UC $=$ Upper Creek; UL = Upper Lake; $\mathrm{VC}=$ Vanishing Creek.

favoured by glacial comminution and freeze-and-thaw processes is still the dominant source of the sediments in Admiralty Bay.

Relative to the bedrock, changes in the major element compositions of the sediments are evaluated by computing the enrichment factor (EF). The EF calculation is based on the degree of mobility of elements, and $\mathrm{Al}$, with its low solubility and mobility under most of the Earth's surface conditions, is widely used as a reference element for the immobility scale (Young \& Nesbitt 1998). By using the following formula and the $\mathrm{Al}_{2} \mathrm{O}_{3}$ contents of the sediment samples, we estimate the elemental changes that occurred during weathering:

$$
\mathrm{EF}=\left(E / \mathrm{Al}_{\text {sediment }}\right) /\left(E / \mathrm{Al}_{\text {bedrock }}\right)
$$

where $E / \mathrm{Al}_{\text {sediment }}$ and $E / \mathrm{Al}_{\text {bedrock }}$ represent the concentrations of the respective element $E$ and of $\mathrm{Al}$ in the sediment and in the bedrock, respectively. The obtained EF values revealed that the changes in elements are less than a factor of 2 and generally represent a slight depletion or enrichment in major elements, except for $\mathrm{Ca}, \mathrm{Na}, \mathrm{K}$ and $\mathrm{P}$ depletion and $\mathrm{Mg}$ enrichment in some sediments, compared to the bedrocks (Fig. 11). Concurrent depletion of $\mathrm{Ca}$ and $\mathrm{Na}$ in the lakes (UL and ML) and associated outflow sediments (UC and MC) along with the VC and TC sediments compared to the bedrock samples appears to have been related to slight alterations of the plagioclase minerals. The existence of appreciable amounts of $\mathrm{Na}$ and Ca-plagioclase in the bedrocks implies a lower degree weathering of the bedrocks. Minor or even a lack of clay minerals in the sediments is consistent with a lower degree of chemical weathering. Alternatively, as suggested by previous studies, $\mathrm{Ca}$ leaching due to organic excretions produced by the lichens that cover the rocks and sediments is also possible (Fig. 2c). Compared to depletion of $\mathrm{Ca}$, particularly in the lake sediments, enrichment of $\mathrm{Na}$, especially in the PFC and EG1 channel sediments, is noticeable, suggesting the influence of marine aerosols on the stream sediments, as observed in the water geochemistry. Among the major elements, $\mathrm{Mg}$ is the most enriched in the stream channel sediments of MC, VC, UC, IV, EG1 and PFC rather than the lake sediments compared to the bedrocks.

Compared to the bedrocks, moderate $\mathrm{K}$ and $\mathrm{P}$ and slight Ti depletion in the PFC, EG1, IV and VC channel sediments are obtained. The bedrock composition, particularly in B2 and B7, in the vicinity of these channel sediments shows intermediate characteristics, and $\mathrm{K}$ depletion is probably controlled by the bedrock composition as well as a mixed source. Even though $\mathrm{Ti}$ is generally considered to be a fairly immobile element during weathering, its depletion from the source has been reported during weathering of granitic rocks (Girty et al. 2003). Depletion of $\mathrm{Ti}$ in the channel sediments therefore suggests a source that is susceptible to weathering reactions. The bedrocks, in particular B2 and B7, which feed the watersheds of the stream channels (PFC, EG1 and IV), contain volcanic glass, which is more susceptible to weathering, and Ti-bearing magnetite. Weathering of volcanic glass and Ti-bearing magnetite may cause the depletion of $\mathrm{Ti}$ in the sediments as observed in previous studies (Nowaczyk 2011). This interpretation is supported by a significant correlation $(R=0.57)$ between the EFs for iron $\left(\mathrm{EF}_{\mathrm{Fe}}\right)$ and $\mathrm{Ti}\left(\mathrm{EF}_{\mathrm{Ti}}\right)$. Enrichment due to hydraulic sorting of the other metals during sediment transport might also be the reason for the relative depletion of $\mathrm{Ti}$ in the channel sediments. A slight enrichment in $\mathrm{Fe}$ and $\mathrm{Mn}$, especially in UL and ML and their outflow channel sediments UC and MC, respectively, suggests that the weathering occurred under oxic conditions. Mineralogical identification of iron oxides in the respective sediments corroborates this interpretation (Fig. S4). 


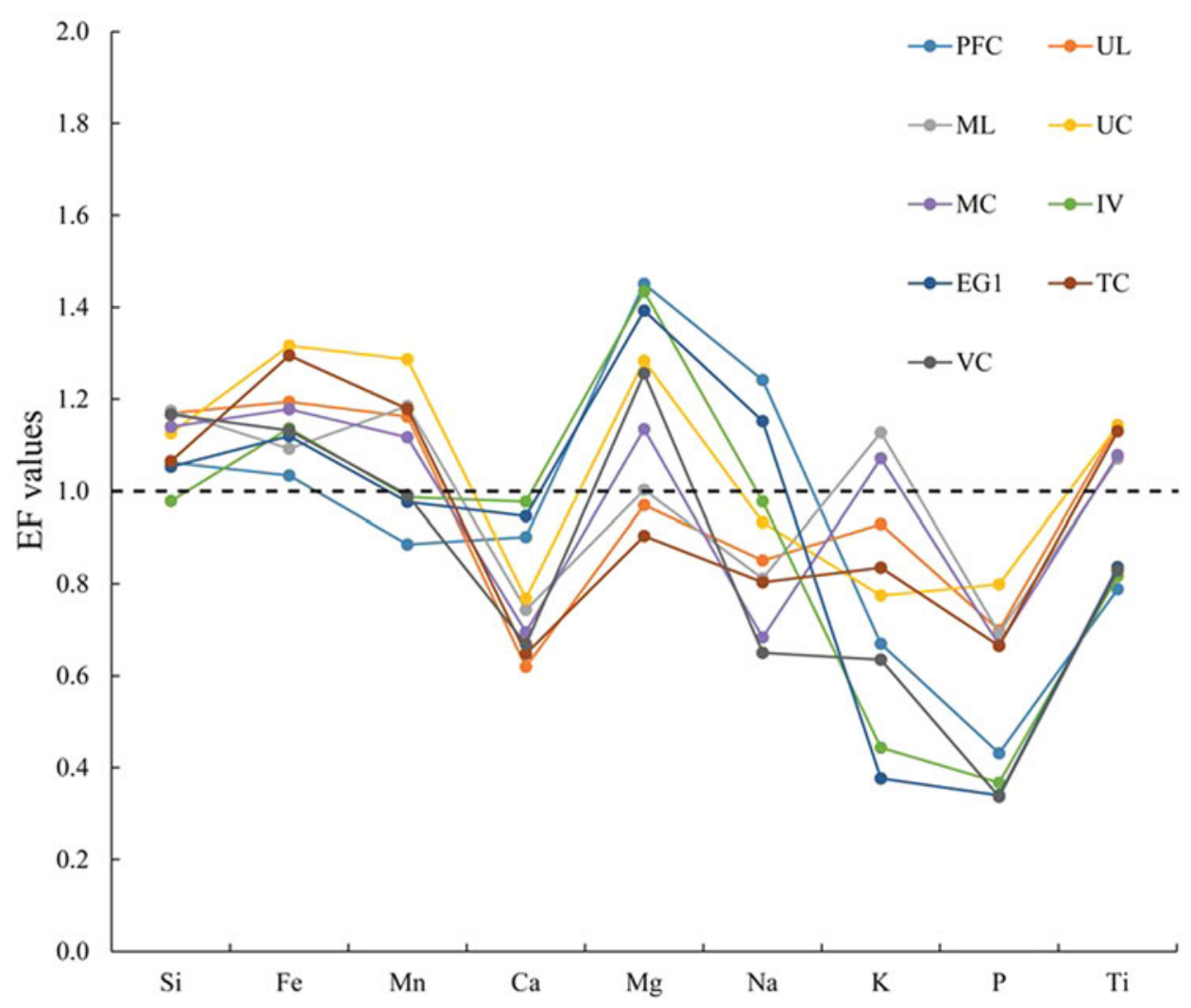

Fig. 11. Spider plot of average Al-normalized major element contents of each sediment unit normalized against the bedrocks. $\mathrm{EF}=$ enrichment factor; $\mathrm{EG}=$ Ecology Glacier Creek; IV = Italian Valley Creek; MC = Mud Creek; ML = Mud Lake; $\mathrm{PFC}=$ Petrified Forest Creek; TC $=$ Tower Creek; UC $=$ Upper Creek; UL $=$ Upper Lake; VC = Vanishing Creek.

Trace element and REE distributions of bedrocks and sediments

Except for $\mathrm{Cs}, \mathrm{Rb}$ and partly $\mathrm{U}$ and $\mathrm{Th}$, all of the sediment samples have similar distribution patterns compared to those of B6, B1, B7 and B2 bedrocks (Fig. 7). Compared to the stream channel sediments obtained from the Ezcurra Inlet site, trace element patterns of the lakes and associated outflow sediments showed enrichments compared to B8 bedrock, but were depleted relative to the rest of the bedrock samples. Compared to the B8 and B1 bedrocks, which generally correspond better to patterns in the lake sediments, slight enrichment of trace elements refers a low degree of chemical weathering in the lake sediments. The REEs of the sediments have very similar distribution patterns to those of the B2 and B7 bedrocks (Fig. 7). Furthermore, all sediment samples have total REE contents that are lower than their respective bedrocks, except for B8, representing a weathered rock sample (74.7\%) (Table III). A lack of significant enrichment of REEs in the respective sediment samples compared to the bedrock samples may indicate a lower degree of chemical weathering of the bedrocks. Most sediment samples show similar fractionated distribution patterns compared to bedrocks, except for B8. It is well demonstrated that REEs are mobile during weathering, particularly during the early stages of weathering (Nesbitt 1979, Condie 1991). Based on the negligible changes in major element contents of the sediments relative to the bedrocks as evidenced by the calculated $\mathrm{EF}$ and ICV values, suggesting a low degree of chemical weathering, REE mobility in surface sediments is assumed to be insignificant. Homogeneous REE distribution patterns in all of the sediment samples evidently imply that the sediment REEs were not affected much during weathering. Moreover, the comparable $\mathrm{La} /(\mathrm{La}+\mathrm{Ce})$ ratios of the sediments with those of the rocks suggest insignificant or a lack of chemical weathering, as a decrease in the ratio would be suggestive of oxidation of $\mathrm{Ce}^{3+}$ to $\mathrm{Ce}^{4+}$, resulting in the production of $\mathrm{Ce}^{4+}$-bearing nanocrystalline weathering products such as hydroxides.

\section{Intensity of chemical weathering}

The Chemical Index of Alteration (CIA), suggested by Nesbitt \& Young (1984), has been successfully and 


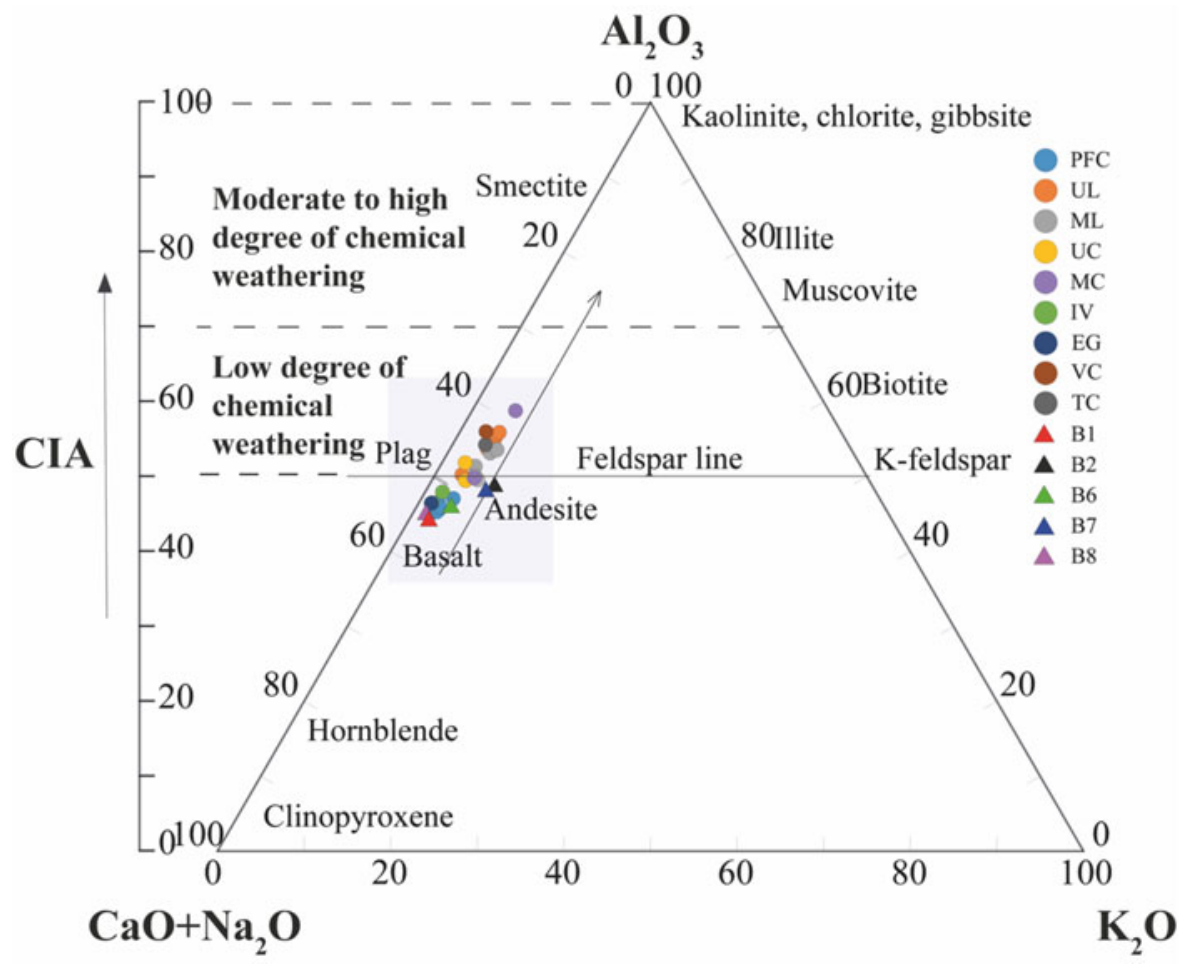

Fig. 12. A-CN-K ternary diagram of sediment and rock samples showing the degree of silicate weathering through the Chemical Index of Alteration (CIA) (Nesbitt \& Young 1984). EG = Ecology Glacier Creek; IV = Italian Valley Creek; MC = Mud Creek; ML = Mud Lake; $\mathrm{PFC}=$ Petrified Forest Creek; TC $=$ Tower Creek; UC $=$ Upper Creek; UL $=$ Upper Lake; VC $=$ Vanishing Creek.

widely used to measure original and primary minerals along with secondary minerals such as clay minerals. The CIA is calculated based on the following formula:

$$
\mathrm{CIA}=\left[\frac{\mathrm{Al}_{2} \mathrm{O}_{3}}{\left(\mathrm{Al}_{2} \mathrm{O}_{3}+\mathrm{CaO}^{*}+\mathrm{Na}_{2} \mathrm{O}+\mathrm{K}_{2} \mathrm{O}\right)}\right] \times 100
$$

where the major oxide values in the formula are expressed as molar proportions. For the calculation of CIA values, $\mathrm{CaO}$ is considered to be sourced only from silicate minerals $\left(\mathrm{CaO}^{*}\right)$. Generally, CIA values for fresh mafic sources are $\sim 30-35$; values $>40$ imply some influence from chemical weathering and values $>50$ are firm evidence for chemical weathering (Nesbitt \& Young 1984).

Generally, CIA values range from $\sim 50$ for fresh rocks to 100 for substantially weathered rocks (i.e. secondary minerals; e.g. kaolinite). The calculated CIA values of all sediment samples ranged between $41.5 \%$ and $56.4 \%$, with a mean of $47.3 \%$ (Table II). In general, these values imply little or no chemical weathering associated with the sediments. The stream channel sediments showed the lowest CIA values amongst all sediments (Table II). For example, PFC sediments had CIA values ranging from $41.5 \%$ to $43.5 \%$ (average $=42.3 \%$ ). Little or no chemical weathering being determined in the studied area corroborates well with previous studies (Necdzarek et al. 2015).

The $\mathrm{Al}_{2} \mathrm{O}_{3}-\left(\mathrm{CaO}^{*}+\mathrm{Na}_{2} \mathrm{O}\right)-\mathrm{K}_{2} \mathrm{O}$ contents of the sediments and bedrocks are used to construct an A-CN-K diagram to further evaluate the degree of chemical weathering in the area. All sediment samples plotted almost parallel to the A-CN boundary and clustered around the feldspar line, resembling the source composition. In Fig. 12, the arrow represents the probable weathering trends of the bedrocks (i.e. basaltic andesite and andesine). All sediments, in particular the PFC, EG and IV stream sediments, closely plot to the weathering trends of basalt and andesite. This order in CIA values of sediment is a good indication of the degree of chemical weathering.

All sediments follow the general weathering trends with minor variations (Fig. 12). A slight shift towards the A-CN line observed in the stream channel sediments (PFC, EG and IV) was most probably related to $\mathrm{K}_{2} \mathrm{O}$ depletion as indicated by $\mathrm{EF}_{\mathrm{K}}$ (Fig. 11). $\mathrm{K}_{2} \mathrm{O}$ is expected to be fixed in the weathering product (clay minerals) compared to $\mathrm{CaO}$ and $\mathrm{Na}_{2} \mathrm{O}$. Therefore, it is improbable that $\mathrm{K}_{2} \mathrm{O}$ depletion in the respective sediments would be caused by chemical weathering as suggested by the lack of weathering products in the sediment compositions. This assumption is also 
evidenced by the CIA values indicating nearly no weathering (Table II). The most plausible explanation is that these sediments may have been mixed with other sediments with relatively low $\mathrm{K}_{2} \mathrm{O}$ contents. This seems possible as fluvial sediments are the main sources for the respective sediments. The presence of seemingly fresh euhedral-shaped pyroxene and plagioclases in the sediments of PFC, IV and EG with low CIA values further confirm the reduced rate of weathering.

Unlike the stream channel sediments, the CIA values of lakes and their associated outflow stream sediments indicate that bedrocks have undergone some degree of chemical weathering, as evidenced by the REE distribution patterns in Fig. 7 (e.g. B8 bedrock). By contrast to what was observed in the stream channel sediments, although they are local, clay minerals were occasionally present as vermiculite and unidentified smectite groups, especially in the lake sediments. The contribution of smectite originating from the transformation of glassy volcanic dusts emitted from a nearby active volcano on Deception Island to the sediments cannot be completely ruled out in the region. The presence of minor amounts of highly localized clay minerals along with comparable ICV and CIA values of the lake sediments are good indications of the low degree chemical weathering of the bedrocks that feed the watersheds of the lakes. Similarly to our results, Vašinka et al. (2020) recently reported the low degree chemical weathering of volcanic rocks, particularly those rich in anorthite, contributing to the Big Lachman Lake sediments.

Consistent with Vašinka et al. (2020), strong consistency exists between the Plagioclase Index of Alteration (PIA) (Fedo et al. 1995) and the CIA values of sediments, indicating that plagioclase, in particular the anorthite component, dominated chemical weathering under mostly oxic conditions, as evidenced by a strong positive correlation $\left(R^{2}=0.93\right)$ between the CIA and the Mafic Index of Alteration (MIA) (Babechuk et al. 2014) values of the sediments, in particular lake sediments (Table II).

There has been a long debate as to what controls the weathering rate of rocks (e.g. climate vs lithology) under Antarctic conditions, particularly following the reporting of a wide range of CIA values. Compared to ADV sediments $(\sim 40-55 \%)$, relatively high CIA values were obtained from the soils of Barton Peninsula, KGI, ranging from $57.5 \%$ to $65.3 \%$, which has been attributed to the moderate climate of KGI (Bishop et al. 2014). However, our CIA values calculated for the sediments of the various components (e.g. streams and lakes) of Admiralty Bay, KGI, located near Barton Peninsula, are comparable with those of ADV sediments. These comparable CIA values suggest that climate may not be the only key factor that influences the weathering rate of rocks. In contrast to the neutral to basic characteristics of the surface waters of Admiralty Bay, acidic surface waters originating from the pyrite-rich andesite covering part of Barton Peninsula probably accelerated the weathering of the rocks, resulting in the higher CIA values.

Future fieldwork is needed to rigorously explore the geological factors affecting these weathering trends. For example, a recent study carried by Hochella et al. (2019) has revealed that particle size may have a greater impact on the chemistry of natural waters, and the influence of nanoparticles in natural waters has been neglected. Therefore, the accuracy of the elemental flux in a given surface water and thus the extent to which fresh water chemistry can faithfully reflect or not reflect the weathering rate of rocks should be reconsidered in future studies, which should be undertaken using proper filtration techniques.

\section{Conclusion}

In general, the major ion compositions of all freshwater bodies in the western part of Admiralty Bay, KGI, are similar and are characterized by the enrichment in $\mathrm{Na}^{+}$, $\mathrm{Ca}^{2+}$ and $\mathrm{Mg}^{2+}$ cations with $\mathrm{CI}^{-}$-rich contents. Compared to the stream channels and meltwaters, excess $\mathrm{Na}^{+}$and $\mathrm{Ca}^{2+}$ along with $\mathrm{HCO}_{3}^{-}$in the lakes and their outflow stream waters are signs of the contemporary chemical weathering of the bedrocks. The Gibbs plots constructed from the water chemistry data and the relatively higher $\mathrm{Na}^{+} / \mathrm{Cl}^{-}(>2)$ and $\mathrm{Ca}^{2+} / \mathrm{Mg}^{2+}(>4)$ ratios of the lake waters and their outflow waters suggest that lakes waters are under the influence of both bedrock weathering and atmospheric precipitation, while the major ions of the streams and meltwaters reflect predominantly atmospheric precipitation. The CIA along with ICV calculations and A-CN-K plot indicate that the stream sediments of Admiralty Bay have undergone minimal or no chemical weathering, while a low degree of chemical alteration has occurred in the lake sediments. The ICV values with slight or no depletion or enrichment compared to the bedrocks along with the larger EF values of $\mathrm{Mg}$ and $\mathrm{Na}$ calculated for the stream channel sediments reflect minimal chemical weathering. A minor presence of secondary products as well as a dominant presence of slightly weathered detrital minerals in the lake sediments are suggestive that the initial stage of chemical weathering occurred largely by elemental loss rather than mineralogical transformation relative to the source rocks.

Taken together, our results suggest that chemical weathering seems insignificant even in the warmer and humid climatic conditions in the Maritime Antarctic region and largely occurs as elemental loss. Additionally, the current study suggests that the physically weathered silicate minerals and rock fragments mixed with atmospheric inputs are the major sources of ions and sediments in the Maritime Antarctic, and the chemical 
weathering of the bedrocks, though slight, is more pronounced in the lake waters and sediments compared to the stream channel sediments. Hence, geochemical analyses of the stream channel sediments in the Maritime Antarctic, such as those found in Admiralty Bay, may provide a more representative composition of the source material, while the lake sediments may demonstrate more dynamic geochemical processes, such as deglaciation-regulated weathering processes.

\section{Acknowledgements}

We would like to thank the 42nd expedition crew for their hospitality and help at Henryk Arctowski Polish Antarctic Station. We would like to thank the reviewers for their constructive comments, which significantly improved the manuscript.

\section{Financial support}

This study was carried under the auspices of the Presidency of the Republic of Turkey, supported by the Ministry of Industry and Technology, and coordinated by Istanbul Technical University (ITU) Polar Research Center (PolReC). This study was conducted within the frame of the bilateral agreement with the Polish Institute of Biochemistry and Biophysics (IBB) and PolReC. This project was supported by TUBITAK (the Scientific and Technological Research Council of Turkey, grant 119Y411) to N. Balci and by the ITU Scientific Research Projects Division (Project ID: 41729).

\section{Author contributions}

NB developed the concepts and approach and performed the data analysis, in addition to writing and editing the manuscript prior to submission. YG performed field sampling and data analysis, in addition to contributing to writing the manuscript.

\section{Supplemental material}

Two supplemental tables and four supplemental figures will be found at https://doi.org/10.1017/S0954102021000560.

\section{References}

Babechuk, M.G., Widdowson, M. \& Kamber, B.S. 2014. Quantifying chemical weathering intensity and trace element release from two contrasting basalt profiles, Deccan Traps, India. Chemical Geology, 363, 10.1016/j.chemgeo.2013.10.027.

BEYER, L. 2002. Geoecology of Antarctic ice-free coastal landscapes: with 59 tables (Vol. 154). Berlin: Springer Science \& Business Media, 429 pp.

Birkenmajer, K. 2003. Admiralty Bay, King George Island (South Shetland Islands, West Antarctica): a geological monograph. Studia Geologica Polonica, 120, 5-73.
Birkenmajer, K., Francalanci, L. \& Peccerillo, A. 1991. Petrological and geochemical constraints on the genesis of Mesozoic-Cenozoic magmatism of King George Island, South Shetland Islands, Antarctica. Antarctic Science, 3, 10.1017/S0954102091000354.

Bishop, J.L., Englert, P.A., Patel, S., Tirsch, D., Roy, A.J., Koeberl, C., et al. 2014. Mineralogical analyses of surface sediments in the Antarctic Dry Valleys: coordinated analyses of Raman spectra, reflectance spectra and elemental abundances. Philosophical Transactions of the Royal Society A: Mathematical, Physical and Engineering Sciences, 372, 20140198.

CondiE, K.C. 1991. Another look at rare earth elements in shales. Geochimica et Cosmochimica Acta, 55, 10.1016/0016-7037(91) 90370-K.

Cox, R., Lowe, D.R. \& Cullers, R.L. 1995. The influence of sediment recycling and basement composition on evolution of mudrock chemistry in the southwestern United States. Geochimica et Cosmochimica Acta, 59, 10.1016/0016-7037(95)00185-9.

Elango, L. \& Kannan, R. 2007. Rock-water interaction and its control on chemical composition of groundwater. In SARKAR, D., DATTA, R. \& Hannigan, R., eds. Concepts and applications in environmental geochemistry. Amsterdam: Elsevier, 229-243.

Fedo, C.M., Wayne Nesbitt, H. \& Young, G.M. 1995. Unraveling the effects of potassium metasomatism in sedimentary rocks and paleosols, with implications for paleoweathering conditions and provenance. Geology, 23, 921-924.

Gaudette, H.E., Flight, W.R., Toner, L. \& Folger, D.W. 1974. An inexpensive titration method for the determination of organic carbon in recent sediments. Journal of Sedimentary Research, 44, 10.1306/ 74D729D7-2B21-11D7-8648000102C1865D.

Girty, G.H., Marsh, J., Meltzner, A., McConnell, J.R., Nygren, D., Nygren, J., et al. 2003. Assessing changes in elemental mass as a result of chemical weathering of granodiorite in a Mediterranean (hot summer) climate. Journal of Sedimentary Research, 73, 10.1306/ 091802730434.

Green, W.J., Angle, M.P. \& Chave, K.E. 1988. The geochemistry of Antarctic streams and their role in the evolution of four lakes of the McMurdo Dry Valleys. Geochimica et Cosmochimica Acta, 52, 10.1016/0016-7037(88)90280-3.

Gunes, Y. \& BALCI, N. 2021. The catalytic effect of the heterotrophic bacterium Virgibacillus marismortui on basaltic rock dissolution under excess nutrient conditions. Geomicrobiology Journal, 38, 10.1080/01490451.2020.1852453.

HaWes, I. \& Brazier, P. 1991. Freshwater stream ecosystems of James Ross Island, Antarctica. Antarctic Science, 3, 10.1017/S0954102091000329.

Hochella, M.F., Mogk, D.W., Ranville, J., Allen, I.C., Luther, G.W., MARR, L.C., et al. 2019. Natural, incidental, and engineered nanomaterials and their impacts on the Earth system. Science, 363,10.1126/science.aau8299.

Kim, J., JeEN, S.-W., Lim, H.S., LeE, J., Kim, O.-S., Lee, H. \& HonG, S.G. 2020. Hydrogeological characteristics of groundwater and surface water associated with two small lake systems on King George Island, Antarctica. Journal of Hydrology, 590, 10.1016/j.jhydrol. 2020.125537.

Le Bas, M.J., Maitre, R.L., Streckeisen, A., Zanettin, B. \& IUGS Subcommission on the Systematics of Igneous Rocks. 1986. A chemical classification of volcanic rocks based on the total alkali-silica diagram. Journal of Petrology, 27, 745-750.

López-Martínez, J., Serrano, E., Schmid, T., Mink, S. \& Linés, C. 2012. Periglacial processes and landforms in the South Shetland Islands (northern Antarctic Peninsula region). Geomorphology, 155-156, 10.1016/j.geomorph.2011.12.018

Marra, K.R., Madden, M.E.E., Soreghan, G.S. \& Hall, B.L. 2015. BET surface area distributions in polar stream sediments: implications for silicate weathering in a cold-arid environment. Applied Geochemistry, 52, 10.1016/j.apgeochem.2014.11.005. 
Mozer, A. 2012. Pre-glacial sedimentary facies of the Point Thomas Formation (Eocene) at Cytadela, Admiralty Bay, King George Island, West Antarctica. Polish Polar Research, 33, 41-62.

NędzareK, A., Tórz, A. \& PodlasińsKa, J. 2015. Ionic composition of terrestrial surface waters in Maritime Antarctic and the processes involved in formation. Antarctic Science, 27, 10.1017/S0954102014000522.

NesbitT, H.W. 1979. Mobility and fractionation of rare earth elements during weathering of a granodiorite. Nature, 279, 10.1038/ 279206a0

Nesbitt, H.W. \& Young, G.M. 1984. Prediction of some weathering trends of plutonic and volcanic rocks based on thermodynamic and kinetic considerations. Geochimica et Cosmochimica Acta, 48, 10.1016/0016-7037(84)90408-3.

NowACZYK, N.R. 2011. Dissolution of titanomagnetite and sulphidization in sediments from Lake Kinneret, Israel. Geophysical Journal International, 187, 10.1111/j.1365-246X.2011. 05120.x.

Obryk, M.K., Doran, P.T., Fountain, A.G., Myers, M. \& McKay, C.P. 2020. Climate from the McMurdo Dry Valleys, Antarctica, 1986-2017: surface air temperature trends and redefined summer season. Journal of Geophysical Research - Atmospheres, 125, 10.1029/ 2019JD032180.

Oerlemans, J. \& Fortuin, J.P.F. 1992. Sensitivity of glaciers and small ice caps to greenhouse warming. Science, 258, 10.1126/science.258. 5079.115 .

Potapowicz, J., Szumińska, D., Szopińska, M., Bialik, R.J., Machowiak, K., Chmiel, S. \& Polkowska, Ż. 2020. Seashore sediment and water chemistry at the Admiralty Bay (King George Island, Maritime Antarctica) - geochemical analysis and correlations between the concentrations of chemical species. Marine Pollution Bulletin, 152, 10.1016/j.marpolbul.2020.110888.

Rutledge, A.M., Horgan, B.H.N., Havig, J.R., Rampe, E.B., Scudder, N.A. \& Hamilton, T.L. 2018. Silica dissolution and precipitation in glaciated volcanic environments and implications for Mars. Geophysical Research Letters, 45, 7371-7381.

Santos, I.R., Fávaro, D.I., Schaefer, C.E. \& Silva-Filho, E.V. 2007. Sediment geochemistry in coastal Maritime Antarctica (Admiralty Bay, King George Island): evidence from rare earths and other elements. Marine Chemistry, 107, 10.1016/j.marchem.2007. 09.006.

Sari, E., Ünlü, S., Balci, N., Apak, R., Kurt, M.A. \& Koldemir, B. 2013. Evaluation of contamination by selected elements in a Turkish port. Polish Journal of Environmental Studies, 22, 841-847.

Sharp, M., Tranter, M., Brown, G.H. \& Skidmore, M. 1995. Rates of chemical denudation and $\mathrm{CO}_{2}$ drawdown in a glacier-covered alpine catchment. Geology, 23, 10.1130/0091-7613(1995)023<0061: ROCDAC $>2.3 . \mathrm{CO} ; 2$.

Sun, S.S. \& McDonough, W.F. 1989. Chemical and isotopic systematics of oceanic basalts; implications for mantle composition and processes. In SAUnders, A.D. \& NorRY, M.J., eds. Magmatism in the ocean basins. London: Geological Society of London, 313-345.

Szopińska, M., Szumińska, D., Bialik, R.J., Chmiel, S., Plenzler, J. \& PolKowSKA, Ż. 2018. Impact of a newly-formed periglacial environment and other factors on fresh water chemistry at the western shore of Admiralty Bay in the summer of 2016 (King George Island, Maritime Antarctica). Science of the Total Environment, 613, 10.1016/j.scitotenv.2017.09.060.

Thorpe, M.T., Hurowitz, J.A. \& Dehouck, E. 2019. Sediment geochemistry and mineralogy from a glacial terrain river system in southwest Iceland. Geochimica et Cosmochimica Acta, 263, 10.1016/ j.gca.2019.08.003.

Toro, M., Camacho, A., Rochera, C., Rico, E., Bañón, M., FernÁNDEZ-VALIENTE, E., et al. 2007. Limnological characteristics of the freshwater ecosystems of Byers Peninsula, Livingston Island, in Maritime Antarctica. Polar Biology, 30, 10.1007/s00300-006-0223-5.

VAŠINKA, M., KRMíčEK, L., VŠIANSKÝ, D., HRBÁČEK, F. \& NÝvLT, D. 2020. Chemical weathering in Antarctica: an example of igneous rock particles in Big Lachman Lake sediments, James Ross Island. Environmental Earth Sciences, 79, 10.1007/s12665-020-08926-3.

Vasyukova, E.V., Oliva, P., Viers, J., Martin, F., Dupré, B. \& Pokrovsky, O.S. 2019. Chemical weathering of mafic rocks in boreal subarctic environment (northwest Russia) under influence of glacial moraine deposits. Chemical Geology, 509, 10.1016/j.chemgeo.2018.12.033.

WALKLey, A. \& Black, I.A. 1934. An examination of the Degtjareff method for determining soil organic matter and a proposed modification of the chromic acid titration method. Soil Science, 37, 10.1097/00010694-193401000-00003.

Young, G.M. \& NesbitT, H.W. 1998. Processes controlling the distribution of $\mathrm{Ti}$ and $\mathrm{Al}$ in weathering profiles, siliciclastic sediments and sedimentary rocks. Journal of Sedimentary Research, 68, $10.2110 /$ jsr.68.448.

Zwoliński, Z., SZPikowski, J. \& WiśniewsKa, K. 2012. Provenance of surface waters on the western coast of Admiralty Bay, King George Island, Antarctica. Zeitschrift für Geomorphologie Supplementary Issues, 56, 123-141.

Zwoliński, Z., Kejna, M., Rachlewicz, G., Sobota, I. \& Szpikowski, J. 2016. Solute and sedimentary fluxes on King George Island. In Beylich, A.A., Doxon, J.C. \& Zwoliński, Z., eds. Source-to-sink fluxes in undisturbed cold environments. Cambridge: Cambridge University Press, 213-237. 